\title{
The Amphibians and Reptiles of the Altamaha River, Georgia
}

\author{
Dirk J. Stevenson ${ }^{1}$ and Jill Stackhouse ${ }^{2}$ \\ ${ }^{1}$ The Orianne Society, Clayton, Georgia 30525, USA \\ ${ }^{2}$ Bemidji State University, Bemidji, Minnesota 56601, USA \\ Photographs by the senior author except where indicated.
}

\begin{abstract}
Field surveys of 59 sites conducted in 1999-2012 and a review of existing museum specimens documented 29 species of amphibians (13 salamanders, 16 anurans) and 36 species of reptiles (1 crocodilian, 5 lizards, 19 snakes, 11 turtles) from the Altamaha River, Georgia and lowland habitats within its associated floodplain. Field sampling methods including visual encounter surveys, dipnetting, frog call surveys, and binocular/canoe/swim surveys for turtles. All were conducted in several distinct habitat types: The river mainstem, the river floodplain (which includes bottomland hardwood forest, alluvial swamps, and oxbow lakes), and perennial seepages associated with north-facing bluffs. Biogeographically, the Altamaha River is a notable influence on the distributions of many amphibians and reptiles. Pitvipers are mostly absent in floodplain habitats along the river; the absence of what is generally perceived as a common semi-aquatic viper (Cottonmouth, Agkistrodon piscivorus) from floodplain wetlands along much of the Altamaha River is intriguing and merits further study. Continued investigations and regular monitoring of reptilian and amphibian populations along the Altamaha River, a remarkable Coastal Plain stream and a wilderness waterway par excellence, are warranted.
\end{abstract}

Key Words: Altamaha River, flood pulse, Georgia, Cottonmouth, reptiles, amphibians, alluvial swamp.

\section{Introduction}

The Altamaha River snakes 137 miles through the Coastal Plain of southern Georgia from its origin at the confluence of the Oconee and Ocmulgee rivers before emptying

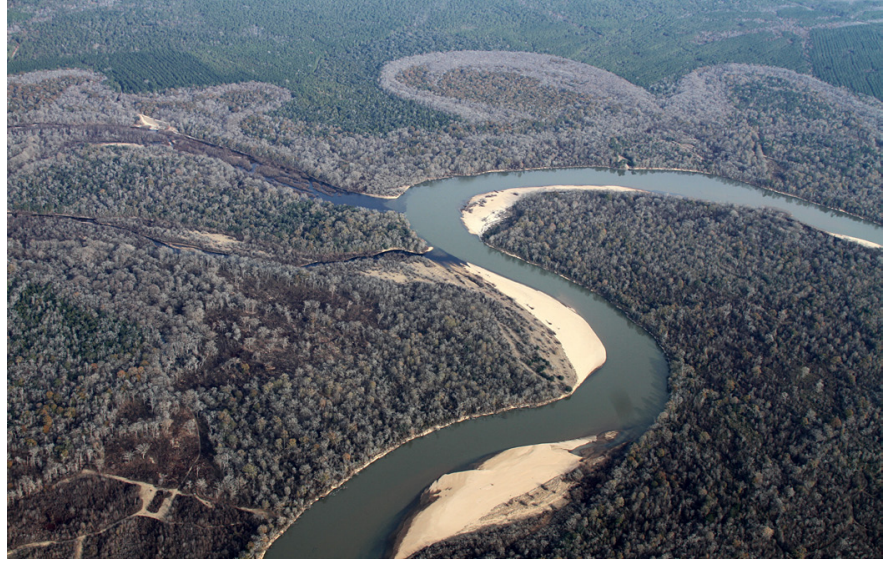

An aerial photo of the Altamaha River taken during low-water conditions at the confluence with the Ohoopee River, a blackwater river and major Coastal Plain tributary. Larger sandbars edging the river are important nesting sites for turtles. Photograph by James R. Holland.

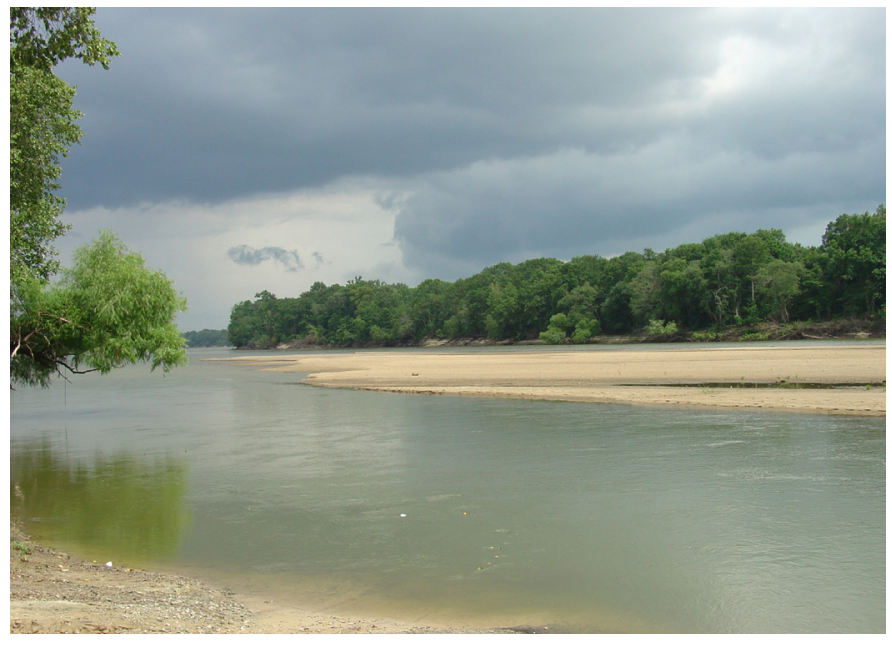

The Altamaha River photographed from Grey's Landing, Toombs County, Georgia.

into the Atlantic Ocean near Darien, Georgia. A forested swampy floodplain, up to five miles wide and encompassing an estimated 170,000 acres, buffers the river. In recognition of its beauty and many unique features, The Nature Conservancy launched the Altamaha River Bioreserve project in 1991, and placed the site on their list of "The 75 Last Great Places.” 


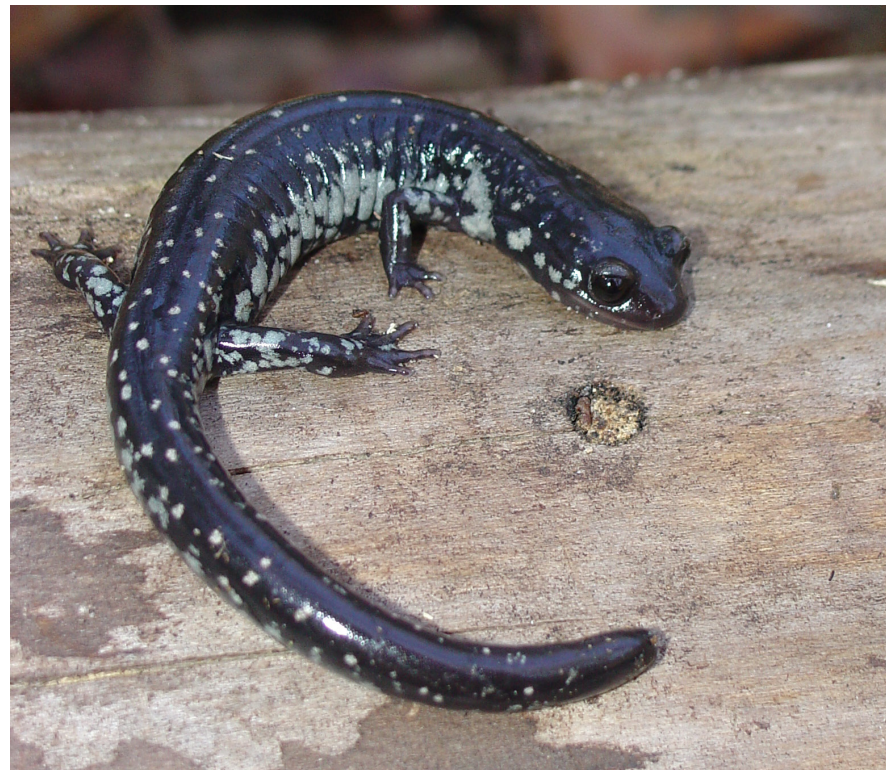

The species in the Slimy Salamander complex that occurs in the Altamaha region is Plethodon ocmulgee, the Ocmulgee Slimy Salamander.
A wild and beautiful stream, the Altamaha River and the habitats along its shores are home to endemic fishes and mussels, rare plants, Swallow-tailed Kites, and the endangered Shortnose Sturgeon. One can visit stands of virgin Bald Cypress over 1,000 years old. Early naturalists William Bartram and Francis Harper traveled here, both writing of the now legendary Franklinia alatamaha (Theaceae), a small, attractive, flowering tree - long extinct in the wild - that is related to camellias and to Loblolly Bay (Gordonia lasianthus).

Natural communities in the Altamaha floodplain include some of the best remaining examples of bottomland hardwood forests and cypress-tupelo swamps in Georgia. A highly productive river delta and estuarine system, including extensive tidal marshes, is present where the river debouches at Darien, Georgia. Although considered one of the great natural treasures of the eastern United States, other than partial species lists (Wharton 1978), very little has been published specific to the herpetofauna of the Altamaha.

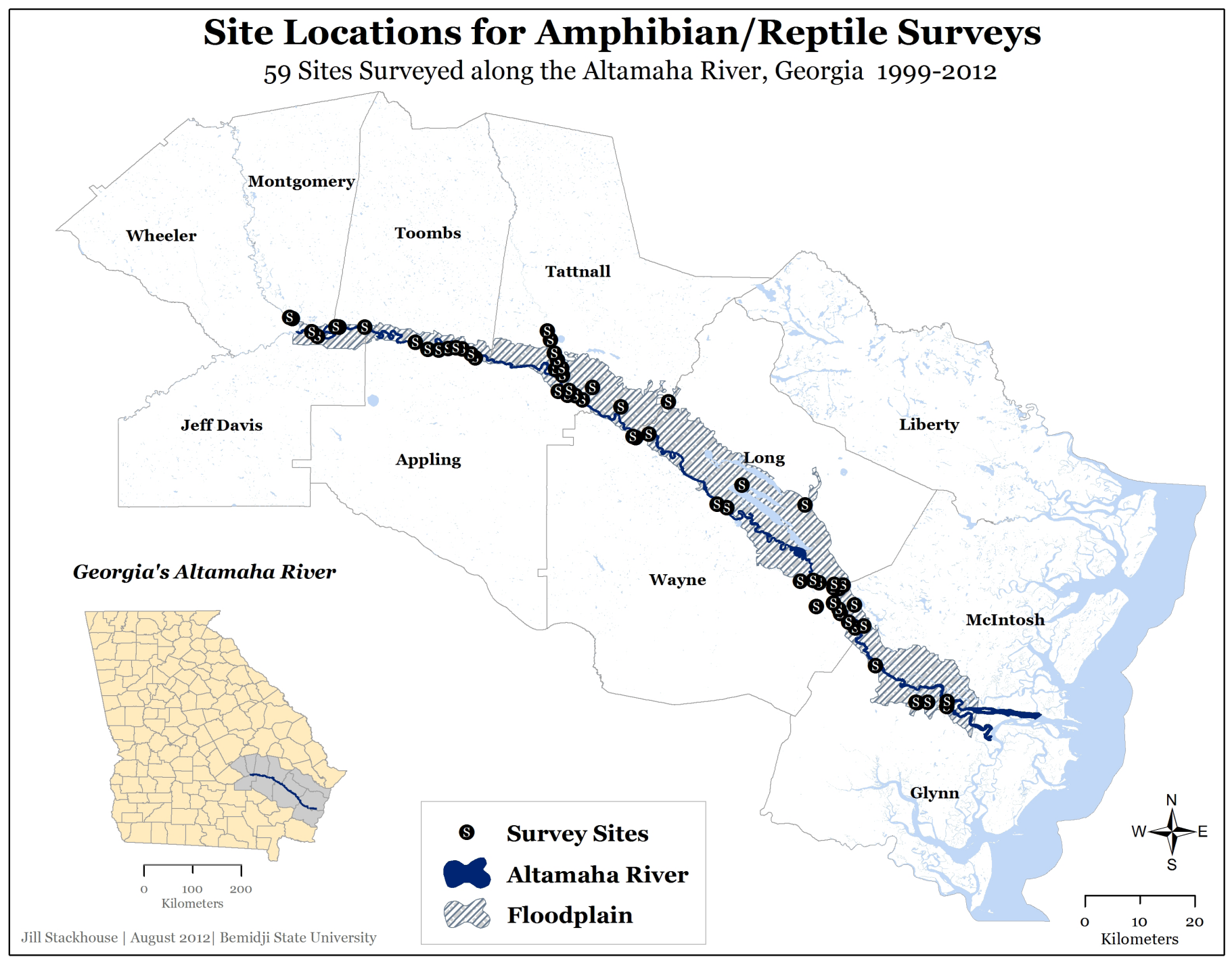

Map 1. Locations of amphibian/reptile survey sites along the Altamaha River, Georgia visited by the authors over a 14-year period (1999-2012). 


\section{Methods}

Over a 14-year period (1999-2012), we conducted surveys for amphibians and reptiles at 59 sites along and within the floodplain of the Altamaha River (Map 1). We visited survey sites on 5-50+ dates, with intensive sampling ( $>25$ visits) conducted at the following public lands, all of which contain extensive acreage of river floodplain (and accompanying bottomland hardwood forest and cypress-tupelo swamp habitats): Big Hammock Wildlife Management Area (WMA, Tattnall County); Moody Forest Natural Area (Appling County); Bullard Creek WMA (Jeff Davis County); Sansavilla WMA (Wayne County); Penholoway Creek WMA (Wayne County); Griffin Ridge WMA (Long County); and Townsend WMA (Long and McIntosh counties). Surveys were conducted yearround and often scheduled to coincide with weather and soil moisture conditions optimal for reptilian and amphibian activity. In addition to the public lands named above, we accessed the river and adjacent floodplain habitats at several dozen public boat landings distributed along the length of the river.

At all survey locations we conducted: (a) Visual encounter surveys - these included flipping surface cover, inspecting logjams and brushpiles, examining the interiors of rotten logs and snags, etc., in an effort to locate animals; (b) dipnet surveys, sorting leaf litter and aquatic vegetation in wetland habitats in search of amphibians and small turtles; and (c) nocturnal amphibian and snake surveys. We conducted frogcall surveys during both autumn-winter and spring-summer breeding periods, and especially following heavy rains.

Aquatic funnel trap and/or minnow trap sampling was conducted at a number of sites. Turtle trapping (i.e., hoop nets baited with sardines) was limited to a few locations, including Moody Forest Natural Area (Stevenson 2002). We experienced success sampling turtles and watersnakes (Nerodia spp.) using binoculars and via "swimming" surveys (i.e., attempt-

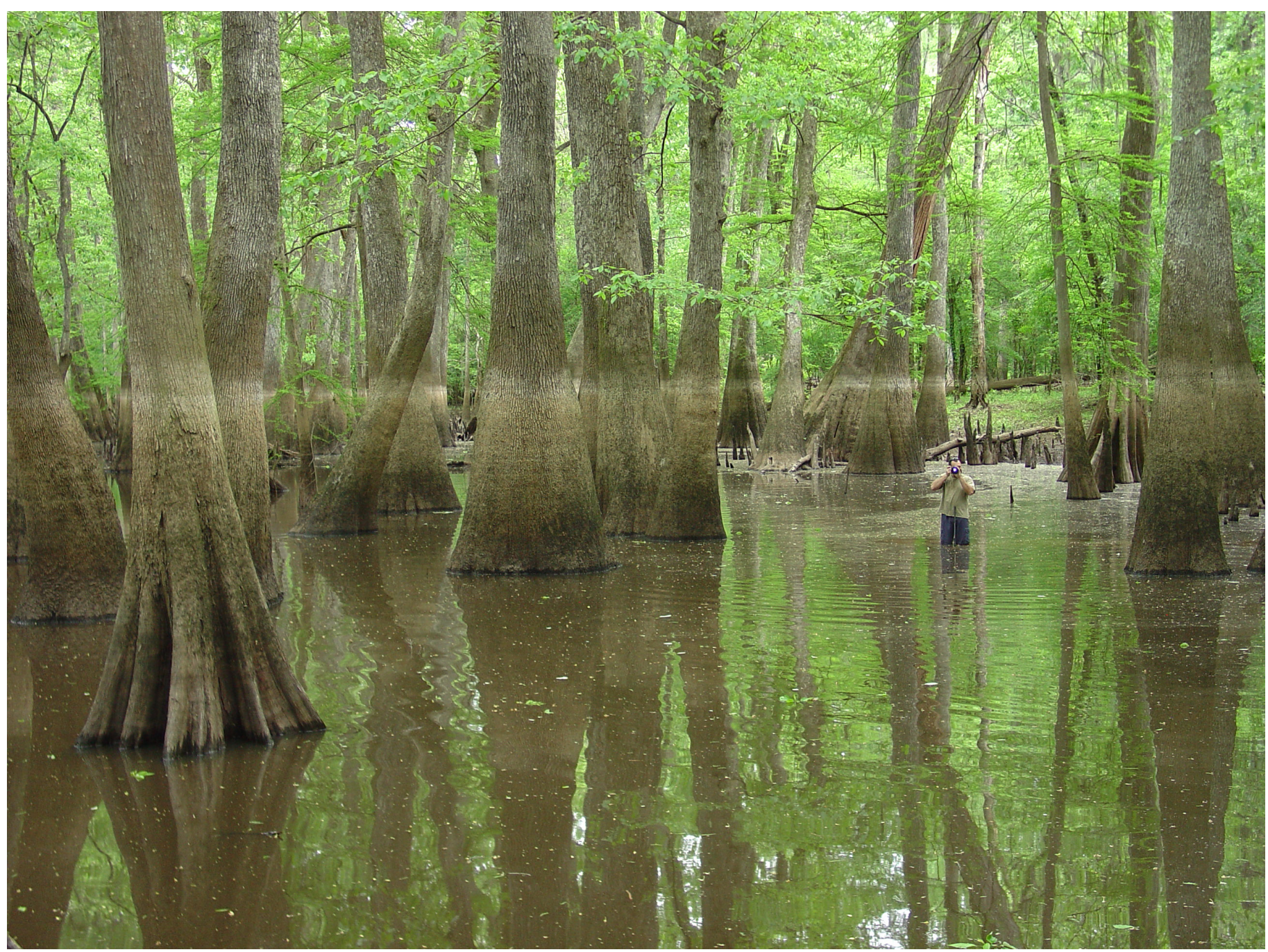

This Altamaha River floodplain swamp on the Moody Forest Natural Area (Appling County, Georgia) is habitat for Bird-voiced Treefrogs (Hyla avivoca), Marbled Salamanders (Ambystoma opacum), Spotted Salamanders (Ambystoma maculatum), Lesser Sirens (Siren intermedia), Striped Mud Turtles (Kinosternon baurii), and Rough Earth Snakes (Virginia striatula). Note the girth of the old-growth Water Tupelos (Nyssa aquatica). 
ing to spot animals basking on limbs and exposed roots while floating downstream).

To complement our field surveys, we located amphibian/reptilian museum and literature records for the Altamaha River and vicinity, consulted Jensen et al. (2008) and Williamson and Moulis (1994), and queried museum collections (University of Georgia, Georgia Southern University, University of Florida) for records (post-1990) for the Altamaha region. In an effort to locate credible Cottonmouth (Agkistrodon piscivorus) records/sightings for the Altamaha drainage, we interviewed a number of natural resource professionals with the Georgia Department of Natural Resources (DNR), the United States Fish and Wildlife Service, and the Department of Defense. Voucher specimens (alcoholic specimens or digital photos) collected during this inventory were deposited in the herpetological collection at Georgia Southern University, Statesboro.

\section{Habitat Types}

Our surveys focused on several distinct habitat types: (1) The mainstem of the Altamaha River itself; (2) lowland habitats present within the river floodplain — including bottomland hardwood forests, cypress-tupelo swamps and sloughs, and oxbow lakes; and (3) perennial seepage areas located in ravines or at the bases of slopes associated with north-facing bluffs.

The Altamaha River can be described as an "alluvial river and swamp system" characterized by numerous abandoned ancient river channels (now sloughs or oxbow lakes). These "river swamp" habitats are dominated by a canopy of Bald Cypress (Taxodium distichum), Ogeechee Lime (Nyssa ogeche), Tupelo Gum (Nyssa aquatica), and Swamp Black Gum (Nyssa biflora; Wharton 1978). Reminiscent of the Amazon River and other mighty rivers, the ecology of the Altamaha floodplain is influenced by dramatically fluctuating water

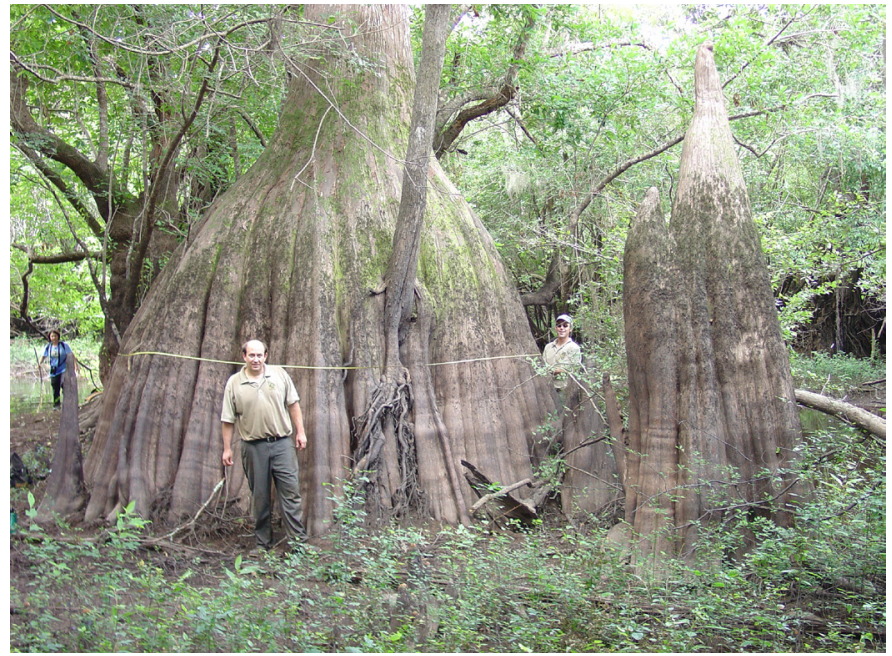

Several groves of ancient Bald Cypress (Taxodium distichum) occur in remote swamps within the Altamaha River floodplain.

levels driven by large annual pulses in flow (Wharton 1978, Stevenson 2010).

Hardwood species typical of bottomland forests within the river floodplain include Overcup Oak (Quercus lyrata) and numerous other oak species, Water Hickory (Carya aquatica), Green Ash (Fraxinus pennsylvanica), and Ironwood (Carpinus caroliniana).

The north side of the river is characterized by a general lack of topography - with a swampy floodplain often up to several miles in width. The south side of the river, by contrast, is sometimes margined by sharp bluffs. Associated with these north-facing bluffs are rich slope forests often referred to as "oak-beech-magnolia" communities, as their dominant constituents include White Oak (Quercus alba), American Beech (Fagus grandifolia), and Southern Magnolia (Magnolia grandiflora). Mucky, perennial seepages are sometimes located at the

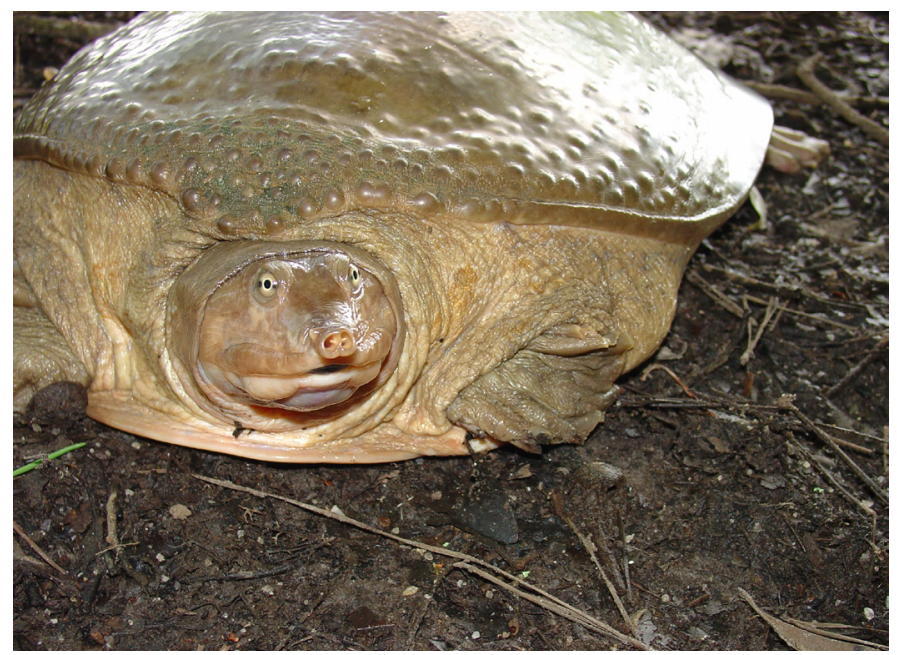

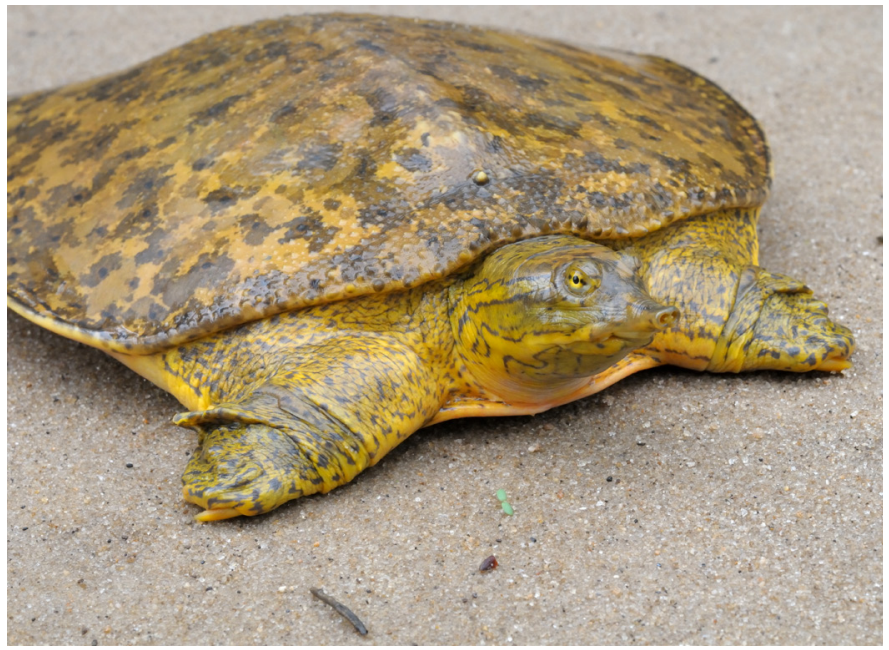

Interestingly, the herpetofauna of the Altamaha region includes a number of lentic versus lotic species pairs. Although the species can be found syntopically, the Gulf Coast Spiny Softshell (Apalone spinifera aspera, left) favors the mild currents of the river mainstem whereas the Florida Softshell (Apalone ferox, right) thrives in the still backwaters of oxbow lakes and sloughs. Gulf Coast Spiny Softshell photograph by James C. Godwin. 
Table 1. Amphibians and reptiles documented from the Altamaha River (Georgia) and lowland habitats associated with the river's floodplain. U = uncommon/rare, $\mathrm{C}=$ common/abundant ( $>15$ locations). 1 = river mainstem, 2 = river floodplain, 3 = perennial seepage/slope forest.

\begin{tabular}{lll} 
AMPHIBIANS & & \\
\hline Salamanders & $\mathrm{C}$ & 2,3 \\
\hline Lesser Siren (Siren intermedia) & $\mathrm{U}$ & 1,2 \\
\hline Greater Siren (Siren lacertina) & $\mathrm{C}$ & 2,3 \\
\hline Two-toed Amphiuma (Amphiuma means) & $\mathrm{U}$ & 2 \\
\hline Spotted Salamander (Ambystoma maculatum) & $\mathrm{C}$ & 2 \\
\hline Marbled Salamander (Ambystoma opacum) & $\mathrm{C}$ & 2 \\
\hline Central Newt (Notophthalmus viridescens louisanensis) & $\mathrm{C}$ & 2 \\
\hline Ocmulgee Slimy Salamander (Plethodon ocmulgee) & $\mathrm{U}$ & 3 \\
\hline Spotted Dusky Salamander (Desmognathus conanti) & $\mathrm{U}$ & 3 \\
\hline Southern Red Salamander (Pseudotriton ruber vioscai) & $\mathrm{C}$ & 2,3 \\
\hline Gulf Coast Mud Salamander (Pseudotriton montanus flavissimus) & $\mathrm{U}$ & 2,3 \\
\hline Southern Two-lined Salamander (Eurycea cirrigera) & $\mathrm{C}$ & 2 \\
\hline Dwarf Salamander (Eurycea quadridigitata) & $\mathrm{C}$ & 2,3 \\
\hline Three-lined Salamander (Eurycea guttolineata) & & \\
\hline Anurans & $\mathrm{C}$ & 2 \\
\hline Southern Toad (Anaxyrus terrestris) & $\mathrm{C}$ & 2 \\
\hline Eastern Narrowmouth Toad (Gastrophryne carolinensis) & $\mathrm{C}$ & 1,2 \\
\hline Northern Cricket Frog (Acris crepitans crepitans) & $\mathrm{C}$ & 2 \\
\hline Florida Cricket Frog (Acris gryllus dorsalis) & $\mathrm{U}$ & 2 \\
\hline Southern Chorus Frog (Pseudacris nigrita nigrita) & $\mathrm{U}$ & 2 \\
\hline Upland Chorus Frog (Pseudacris feriarum) & $\mathrm{C}$ & 2 \\
\hline Spring Peeper (Pseudacris crucifer) & $\mathrm{C}$ & 2 \\
\hline Squirrel Treefrog (Hyla squirella) & $\mathrm{C}$ & 1,2 \\
\hline Green Treefrog (Hyla cinerea) & $\mathrm{C}$ & 2 \\
\hline Cope's Gray Treefrog (Hyla chrysoscelis) & $\mathrm{C}$ & 2 \\
\hline Bird-voiced Treefrog (Hyla avivoca) & $\mathrm{C}$ & 1,2 \\
\hline Southern Leopard Frog (Lithobates sphenocephala) & $\mathrm{C}$ & 1,2 \\
\hline Bullfrog (Lithobates catesbeiana) & $\mathrm{C}$ & 1,2 \\
\hline River Frog (Lithobates heckscheri) & $\mathrm{C}$ & 2 \\
\hline Bronze Frog (Lithobates clamitans clamitans) & $\mathrm{U}$ & 1 \\
\hline Pig frog (Lithobates grylio) & \\
\hline
\end{tabular}

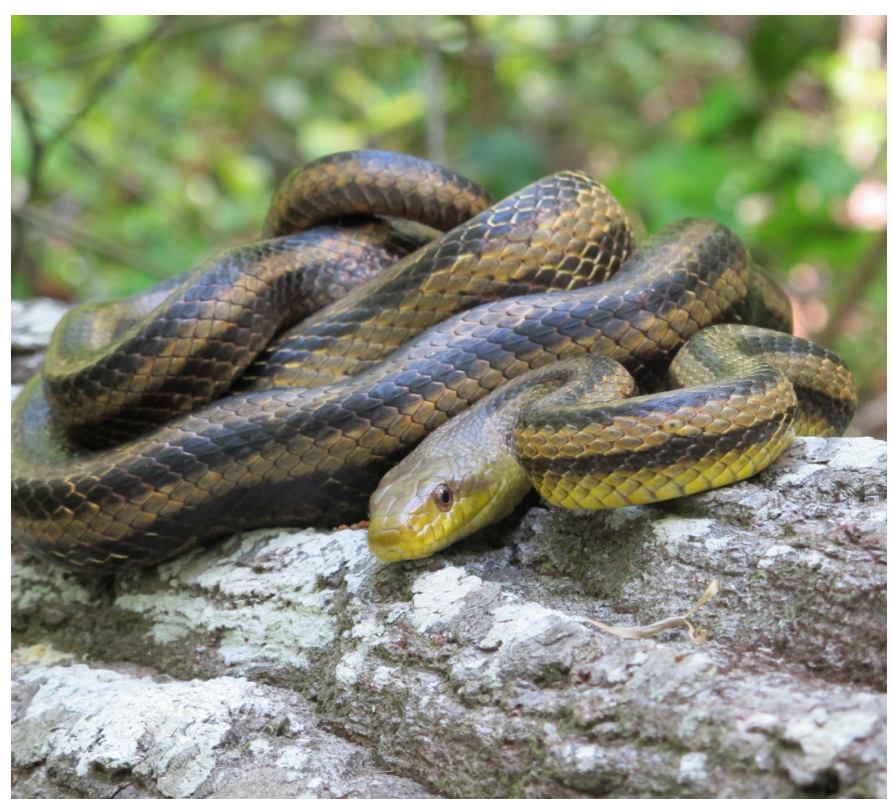

Eastern Ratsnakes (Pantherophis alleghaniensis) are common in bottomland hardwood forests and swamps adjacent to the Altamaha River.

\section{REPTILES}

Crocodilians

American Alligator (Alligator mississippiensis) $\quad$ C $\quad 1,2$

\section{Turtles}

Common Musk Turtle (Sternotherus odoratus) $\quad$ C $\quad 1,2$

Loggerhead Musk Turtle (Sternotherus minor minor) $\quad$ C 1

Striped Mud Turtle (Kinosternon baurii) $\quad$ C 2

Eastern Box Turtle (Terrapene carolina carolina) $\quad$ C $\quad 2,3$

Spotted Turtle (Clemmys guttata) $\quad$ U 2

Yellowbelly Slider (Trachemys scripta scripta) $\quad$ C 1,2

Eastern River Cooter (Pseudemys concinna) $\quad$ C $\quad 1,2$

Florida Cooter (Pseudemys floridana) $\quad$ U 2

Common Snapping Turtle (Chelydra serpentina serpentina) $\quad$ C 1,2

Florida Softshell (Apalone ferox) $\quad$ C 1,2

Gulf Coast Spiny Softshell (Apalone spinifera aspera) $\quad$ C $\quad 1,2$

Squamates (lizards)

Green Anole (Anolis carolinensis) $\quad$ C $\quad 2,3$

Ground Skink (Scincella lateralis) $\quad$ C 2,3

Five-lined Skink (Plestiodon fasciatus) $\quad$ C $\quad 2,3$

Broadhead Skink (Plestiodon laticeps) $\quad$ C 2,3

Southern Fence Lizard (Sceloporus undulatus undulatus) $\quad$ U 3

Squamates (snakes)

\begin{tabular}{lll}
\hline Banded Watersnake (Nerodia fasciata fasciata) & C & 1,2 \\
\hline Brown Watespilota)
\end{tabular}

Brown Watersnake (Nerodia taxispilota) $\quad$ C 1,2

\begin{tabular}{lll}
\hline Redbelly Watersnake (Nerodia erythrogaster erythrogaster) & C & 1,2 \\
\hline
\end{tabular}

Glossy Crayfish Snake (Regina rigida rigida) $\quad$ U 2

Rough Earth Snake (Virgina striatula) U 2

Redbelly Snake (Storeria occipitomaculata) $\quad$ U 2

Brown Snake (Storeria dekayi) $\quad$ U 2

Peninsula Ribbon Snake (Thamnophis sauritus sackenii) $\quad$ U 2

Eastern Garter Snake (Thamnophis sirtalis sirtalis) $\quad$ U $\quad 2,3$

Southern Ringneck Snake (Diadophis punctatus punctatus) $\quad$ C $\quad 2,3$

Rough Green Snake (Opheodrys aestivus) $\quad$ C 2

Eastern Mud Snake (Farancia abacura abacura) $\quad$ U 2

\begin{tabular}{lll}
\hline Common Rainbow Snake (Farancia erytrogramma erytrogramma) C & 1,2 \\
\hline
\end{tabular}

Southern Black Racer (Coluber constrictor priapus) $\quad$ C 2

Eastern Ratsnake (Pantherophis alleghaniensis) $\quad$ C 2

Scarlet Kingsnake (Lampropeltis elapsoides) $\quad$ U 2

Eastern Kingsnake (Lampropeltis getula getula) U 2

Eastern Cottonmouth (Agkistrodon piscivorus piscivorus) U 2

Eastern Diamondback Rattlesnake (Crotalus adamanteus) $\quad$ U $\quad 2,3$

bases of these bluffs or along small ravine streams that flow short distances downslope before joining the river floodplain. These habitats often harbor a high diversity and biomass of salamanders (Means 2000, Stevenson 2011).

\section{Results and Discussion}

Our 1999-2012 surveys of the Altamaha River documented 29 amphibian and 36 reptilian species comprised of 11 salamander species, 14 anurans, 1 crocodilian, 11 turtles, 5 lizards, and 19 snakes (Table 1). New county records and collections representing range extensions are reported in Stevenson et al. (2009b, 2011), Jensen et al. (2011), Butler et al. (in press), and Day and Stevenson (in press). Records for three additional species - Greater Siren (Siren lacertina), Pig Frog 


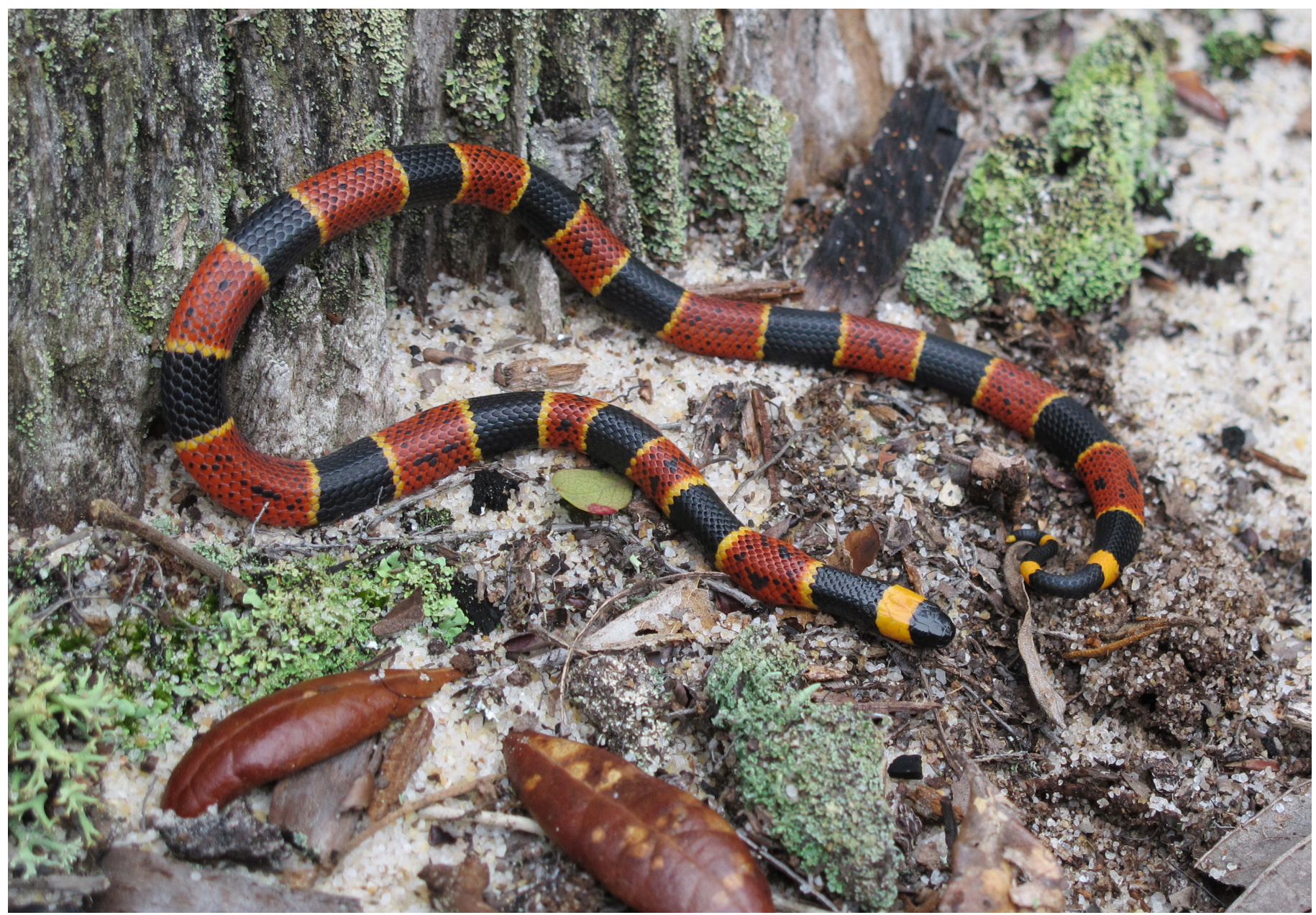

This Eastern Coral Snake (Micrurus fulvius) was found on a vast sand ridge above the Altamaha. Although not found during our surveys, individuals of this species almost certainly make occasional sojourns that carry them into the floodplain.

(Lithobates grylio), and Eastern Ribbon Snake (Thamnophis sauritus sackenii) — never observed on our surveys were reported for the study area by Williamson and Moulis (1994). For each of these species, museum specimens were collected from the lower-most portion of the river near Darien; all three of these species are partial to marshy habitats, and both the

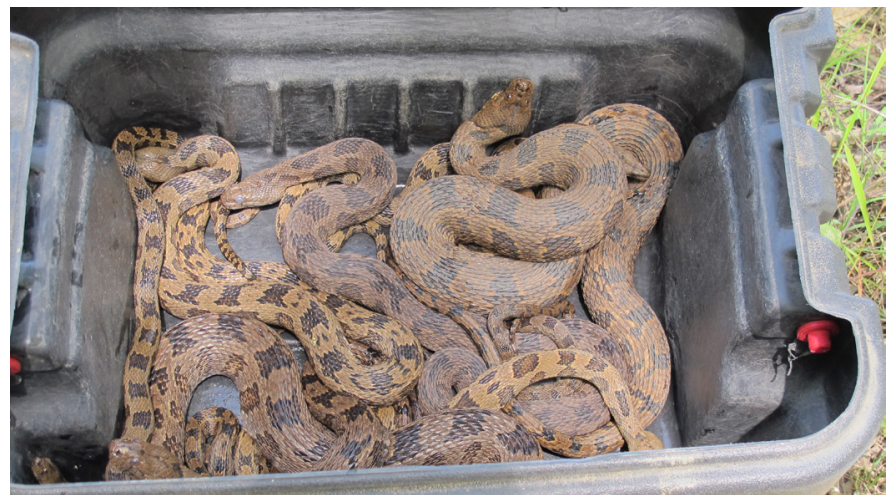

Brown Watersnakes (Nerodia taxispilota) found basking on limbs and roots near the river's edge; this species is the most commonly observed aquatic snake along the river.
Pig Frog and Greater Siren often inhabit open-water habitats with dense aquatic vegetation.

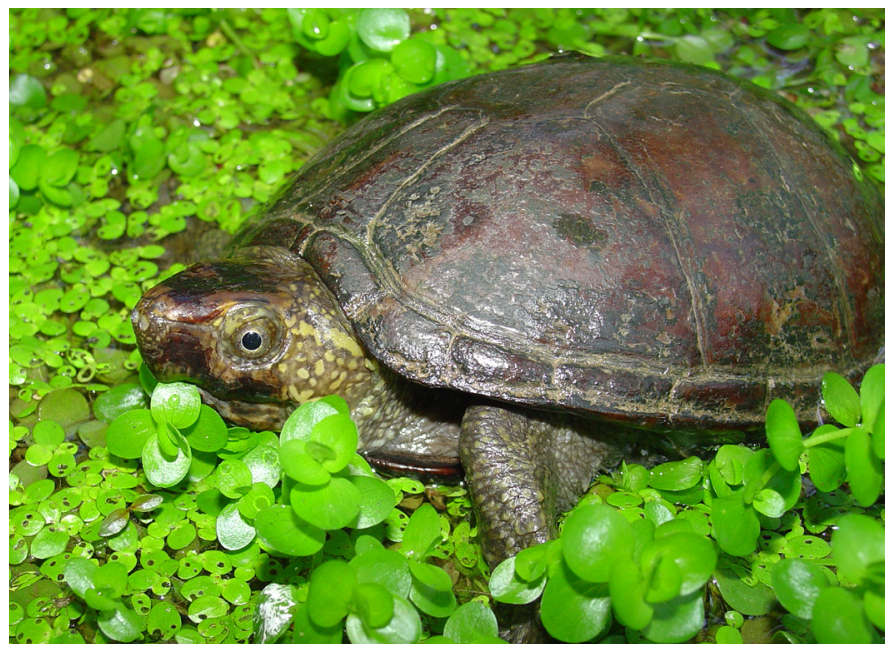

In southern Georgia, Striped Mud Turtles (Kinosternon baurii) are most commonly encountered in floodplain swamps fringing major Coastal Plain streams. Stripes are rarely evident on carapaces of adults from this region. 
The richest species diversity (ca. 50 species of amphibians and reptiles combined) was recorded at Big Hammock WMA, Moody Forest Natural Area, and Bullard Creek WMA. Although undocumented by direct observations, several upland species of snakes not listed in Table 1 might be expected to occasionally traverse or forage in the river flood-
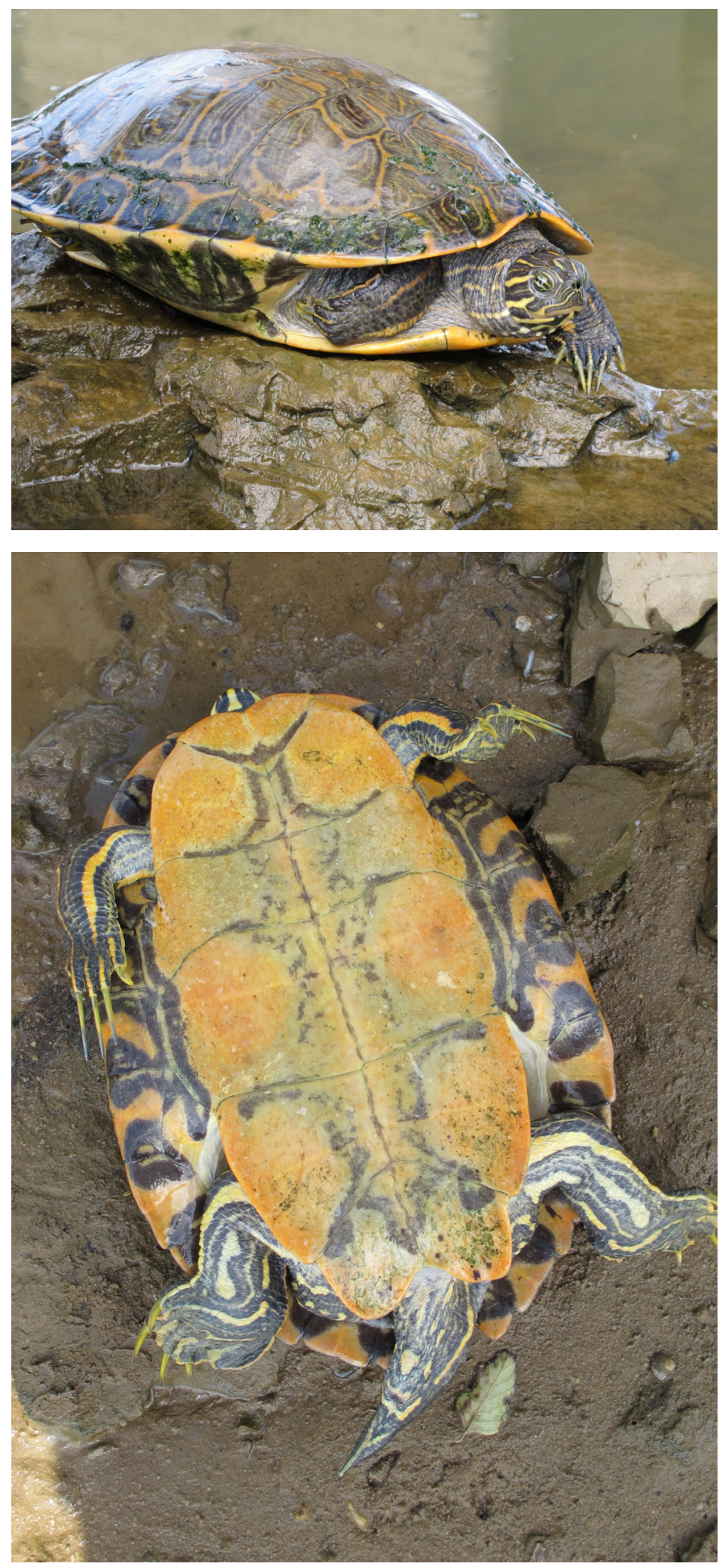

Our survey documented the Eastern River Cooter (Pseudemys concinna), a large, fleet-swimming emydid turtle and a vegetarian, throughout most of the mainstem of the Altamaha River.

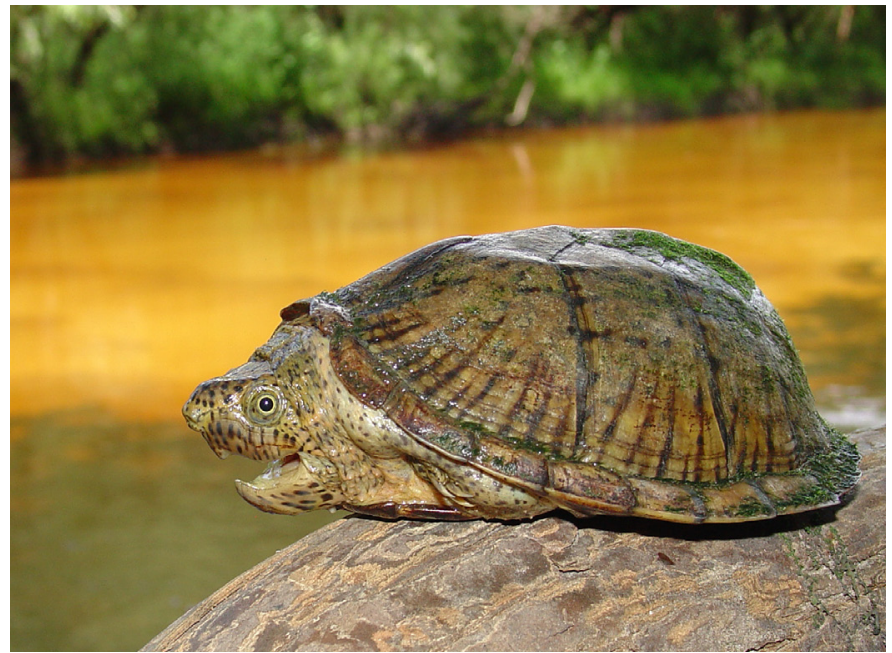

Populations of the mollusc-eating Loggerhead Musk Turtle (Sternotherus minor minor), a species characteristic of the river mainstem, have not been documented downstream of Jesup (Wayne County); this is almost certainly attributable to the decline of native Pearly Mussels (Unionidae) from this section of the river.

plain (e.g., Eastern Indigo Snake, Drymarchon couperi; Red Rat Snake, Pantherophis guttatus, Eastern Hognose Snake, Heterodon platirhinos; Eastern Coral Snake, Micrurus fulvius; and Pigmy Rattlesnake, Sistrurus miliarius). During our surveys we observed several adult Eastern Diamondback Rattlesnakes (Crotalus adamanteus) that appeared to be foraging in oak bottoms within the floodplain.

Per my survey results, reptilian species characteristic $(>15$ localities documented by this survey) of the river mainstem include the Brown Watersnake (Nerodia taxispilota), Gulf Coast Spiny Softshell (Apalone spinifera aspera), Loggerhead Musk Turtle (Sternotherus minor minor), and Eastern River Cooter (Pseudemys concinna). Reptiles and amphibians characteristic (i.e., >15 localities) of bottomland hardwood forests and forested wetlands in the river floodplain include the Lesser Siren (Siren intermedia), Dwarf Salamander (Eurycea quadridigitata), Bird-voiced Treefrog (Hyla avivoca), River Frog (Lithobates heckscheri), Striped Mud Turtle (Kinosternon baurii), and Redbelly Watersnake (Nerodia erythrogaster erythrogaster).

Perennial seepage habitats associated with north-facing bluffs were found to harbor a high diversity and biomass of salamanders, including two species restricted to this habitat type: The Southern Red Salamander (Pseudotriton ruber vioscai) and the Spotted Dusky Salamander (Desmognathus conanti). Three-lined Salamanders (Eurycea guttolineata) and Southern Two-lined Salamanders (Eurycea cirrigera) are very common here. Most examples of this habitat type are located on the south side of the river in Wayne County and are also home to a rare spiketail dragonfly (Cordulegaster sayi; Stevenson et al. 2009a). Like the Southern Red Salamander, the aquatic larvae of $C$. sayi occupy a specialized habitat 

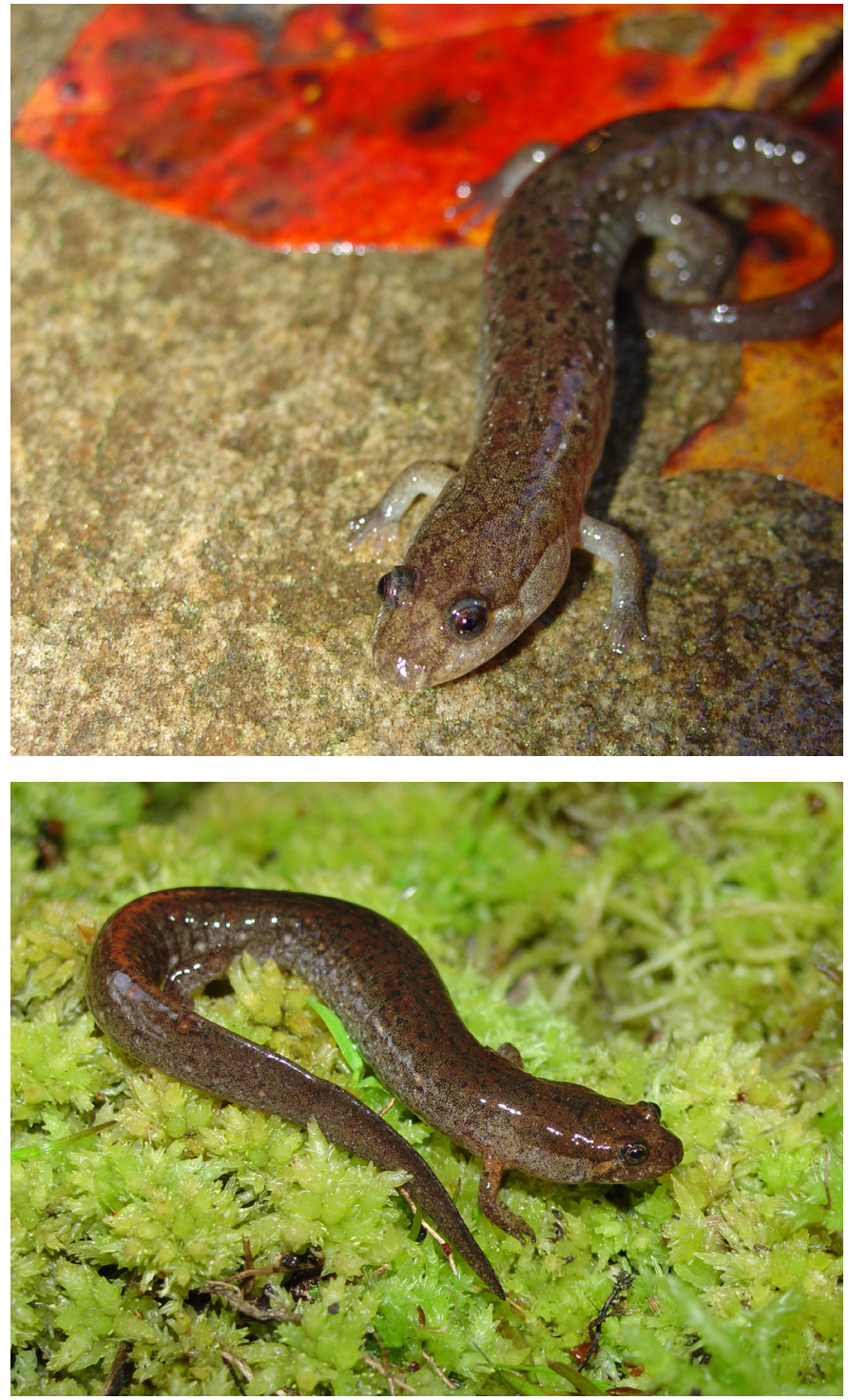

Only one population of the Spotted Dusky Salamander (Desmognathus conanti, top) was documented by our inventory. The rare and declining Southern Dusky Salamander (Desmognathus auriculatus, bottom), a confirmed denizen of acidic and mucky blackwater creek swamps, has not been collected from floodplain wetlands along the Altamaha River.

(mucky seepages) and require 2-3 years to complete development. Extensive bluff-and-seepage habitats near the Jaycee's public boat landing in Jesup support large salamander populations; currently, this is the only known site for D. conanti along the Altamaha. Long-term protection of this site should be implemented.

Notable absentees include Broad-striped Dwarf Sirens (Pseudobranchus striatus striatus), Black Swamp Snakes (Seminatrix pygaea), Southern Copperheads (Agkistrodon contortrix contortrix), and Timber Rattlesnakes (Crotalus horridus), none of which have been documented from the Altamaha River or its floodplain. We suspect that Dwarf Sirens and Swamp Snakes might eventually turn up in freshwater marsh or swamp habitats along the lower part of the

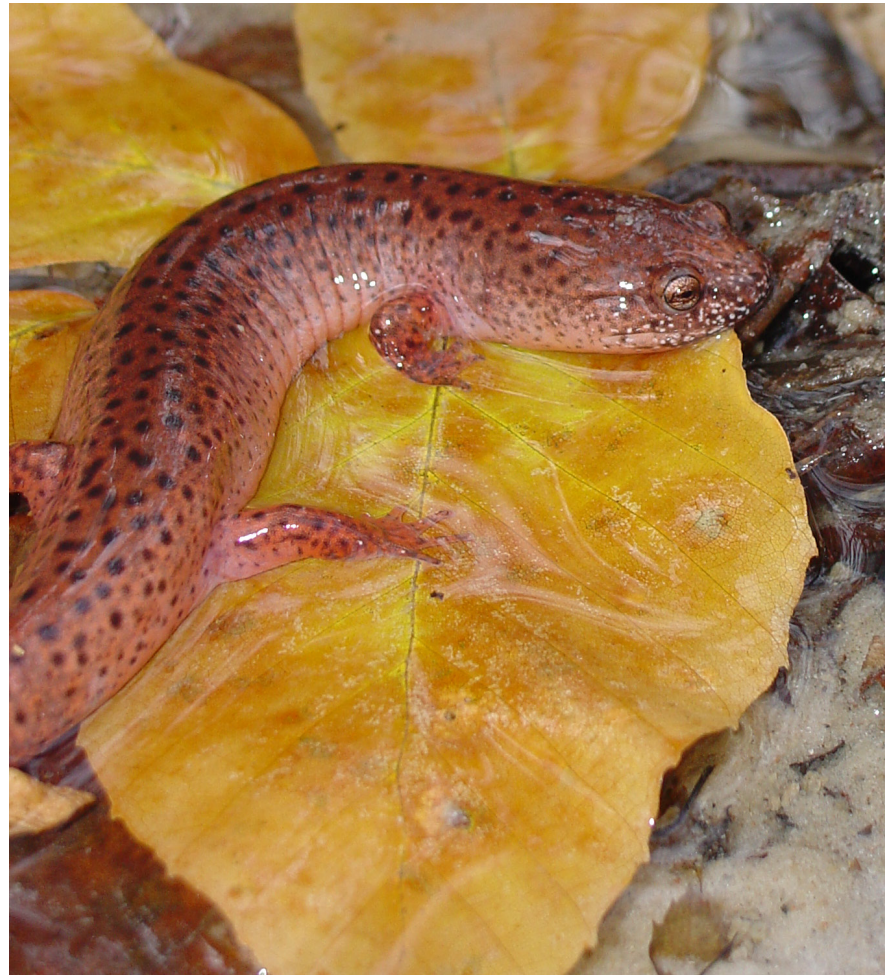

A confirmed seepage critter, the Southern Red Salamander (Pseudotriton ruber vioscai) is limited to springs and rivulets associated with north-facing river bluffs.

river. Generally, the floodplain lacks extensive tracts of deciduous forest or mixed pine-oak forest habitats preferred by the two vipers, although sites like Moody Forest Natural Area and Bullard Creek WMA seem to be notable exceptions. An adult Copperhead was recovered from the belly of a large Eastern Indigo Snake found DOR near the edge of the Altamaha floodplain (Doctor's Creek, ca. 4.0 mi SE Ludowici, Long County; Stevenson et al. 2010).

Also missing from our Altamaha collections and not represented by museum collections are two salamanders

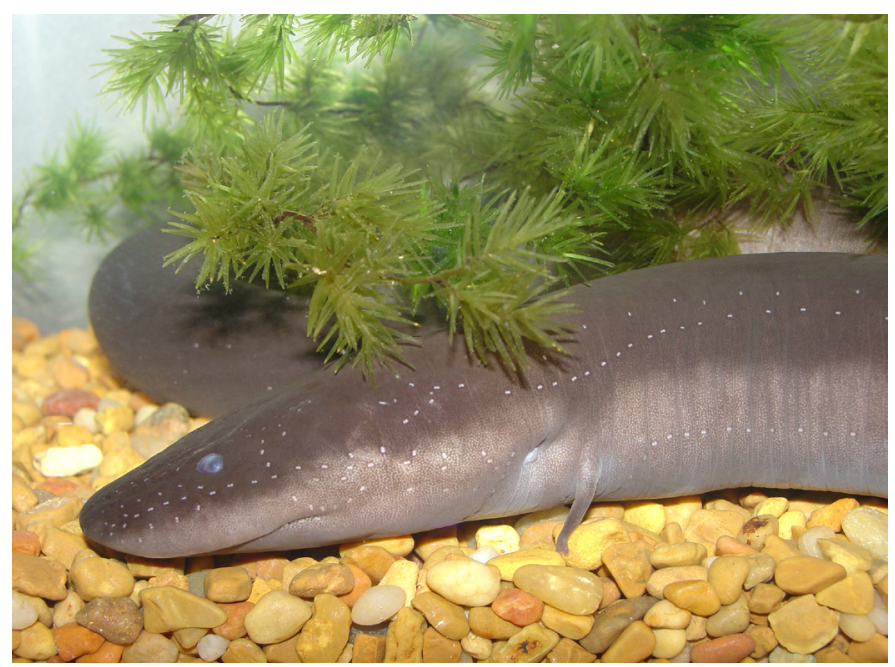

A Two-toed Amphiuma (Amphiuma means) from southern Georgia. 


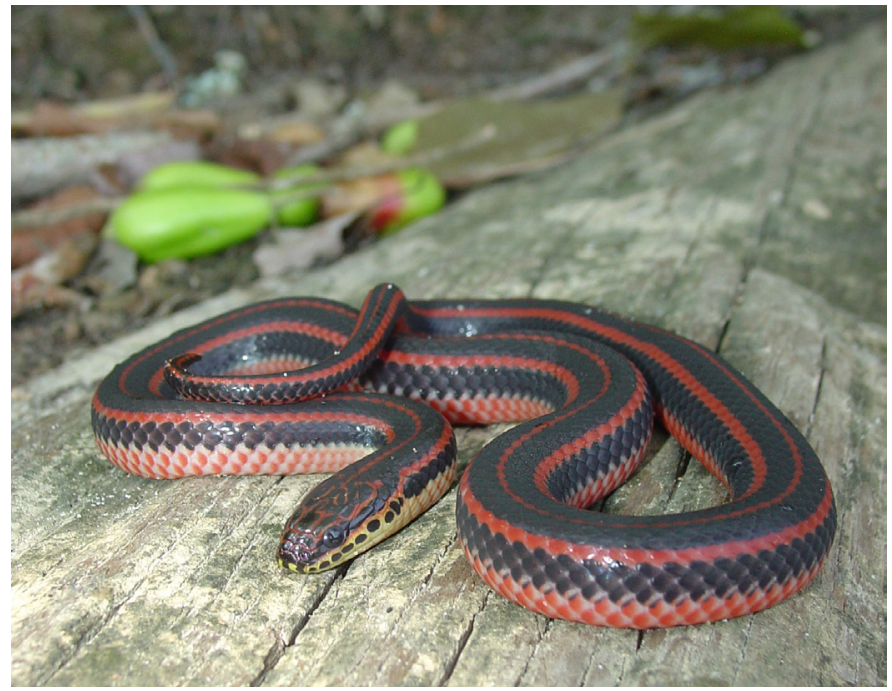

The secretive and aquatic Rainbow Snake (Farancia erytrogramma) is difficult to locate in the field. Adults have a specialized diet, feeding primarily on American Eels (Anguilla rostrata).

commonly associated with muck-floored, acidic blackwater creek swamps in southern Georgia (a habitat subtly different from those alluvial river swamps lining the Altamaha): The Southern Dusky Salamander (Desmognathus auriculatus) and the Many-lined Salamander (Stereochilus marginatus; Means 2000, Beamer and Lamb 2008). Many old records (e.g., see Williamson and Moulis 1994) for D. auriculatus from sites near the Altamaha proved to be misidentified Desmognathus conanti; the enigmatic $D$. auriculatus is currently known from very few locations in southern Georgia, but has recently been collected from a blackwater swamp adjacent to a tributary stream of the Altamaha (Beamer and Lamb 2008, Graham et al. 2010).

We documented several species that are tracked as "Special Concern Animal Species" by the Georgia DNR

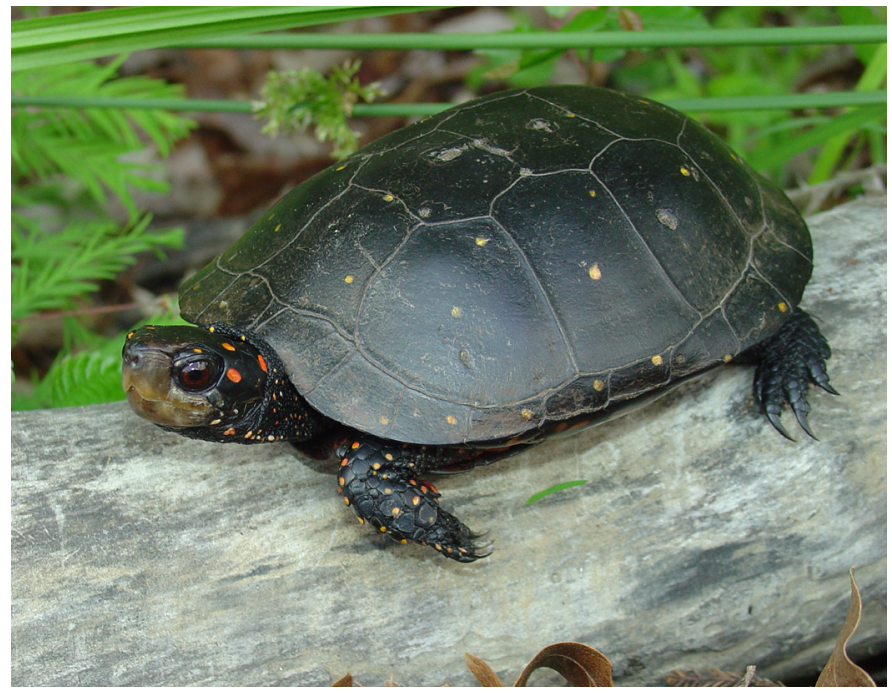

Little is known about Spotted Turtles (Clemmys guttata) in southern Georgia. Our survey documented but a single population from a large floodplain swamp along the Altamaha.
(Jensen et al. 2008). These included the Spotted Turtle (Clemmys guttata, also state-listed as "Rare"), Common Rainbow Snake (Farancia erytrogramma erytrogramma), and Eastern Diamondback Rattlesnake (Crotalus adamanteus). Populations of the federally threatened Eastern Indigo Snake (Drymarchon couperi) are present on sand ridges proximal to and above the Altamaha River floodplain; given this species' migratory nature, with foraging adults often dispersing great distances from the Gopher Tortoise (Gopherus polyphemus) colonies on sand ridges where they overwinter, some individuals almost certainly move to low habitats along the river (Stevenson et al. 2008). The "dry pine hills, south of the Alatamaha" River (Wayne County) is the type locality for this handsome and iconic serpent (McCranie 1980), and lands within the Altamaha River drainage remain a population stronghold (Stevenson et al. 2010).

The lone Spotted Turtle record for the Altamaha is represented by an adult male that we found in a vast freshwater swamp in Glynn County (Stevenson et al. 2009b). Another record is for a blackwater swamp close to the Ohoopee River (Tattnall County; Georgia Natural Heritage Program database, Social Circle), a major Coastal Plain tributary of the Altamaha. This species, poorly known and rarely encountered in southern Georgia, is known to occupy tidally influenced wetlands (D. Stevenson, pers. obs.).

The highly aquatic, clandestine, and often nocturnal Rainbow Snake is singularly difficult to locate in the field. However, a number of recent records suggest that the Altamaha supports a robust population of this American Eel (Anguilla rostrata)-eater. We collected two yearlings from floodplain swamps close to the Altamaha by raking saturated muck in drying pools. Small Lesser Sirens (Siren intermedia), potential prey items, were found close to the snakes on both occasions.

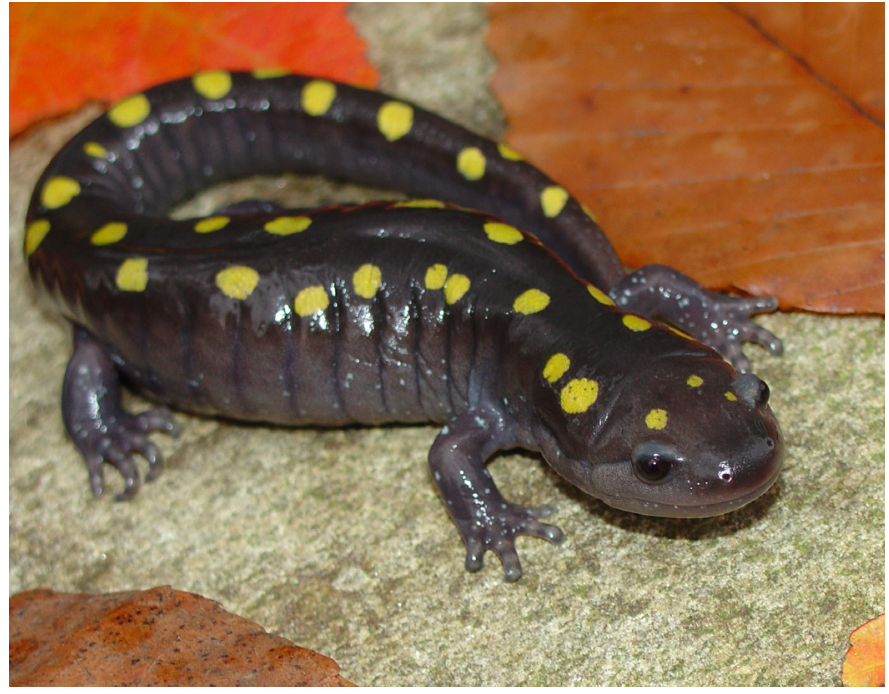

Spotted Salamanders (Ambystoma maculatum) are one of several amphibians with ranges that extend into the Coastal Plain of southeastern Georgia via the broad corridor of bottomland forest that fringes the Altamaha River. 


\section{Biogeography}

A number of amphibian and reptilian species are entirely absent (or mostly so) from that portion of the Atlantic Coastal Plain of southeastern Georgia that lies south of the Altamaha River and its associated floodplain. These species include the Upland Chorus Frog (Pseudacris feriarum), Bird-voiced Treefrog, Northern Cricket Frog (Acris crepitans crepitans), Spotted Salamander (Ambystoma maculatum), and Eastern River Cooter (Williamson and Moulis 1994, Jensen et al. 2008, this study). The distributions of the Southern Red Salamander and the Three-lined Salamander essentially exhibit the same pattern, although populations of each are known from the upper Satilla River drainage in central Coffee County (Williamson and Moulis 1994). The southernmost extent of the Dwarf Waterdog's (Necturus punctatus) range is the Altamaha River drainage (tributary streams of the Ocmulgee River; the species has never been verified from the mainstem of the Altamaha River; Jensen et al. 2008).

Several amphibian taxa typical of mesic forests (and more northerly climes) appear to extend their ranges into the
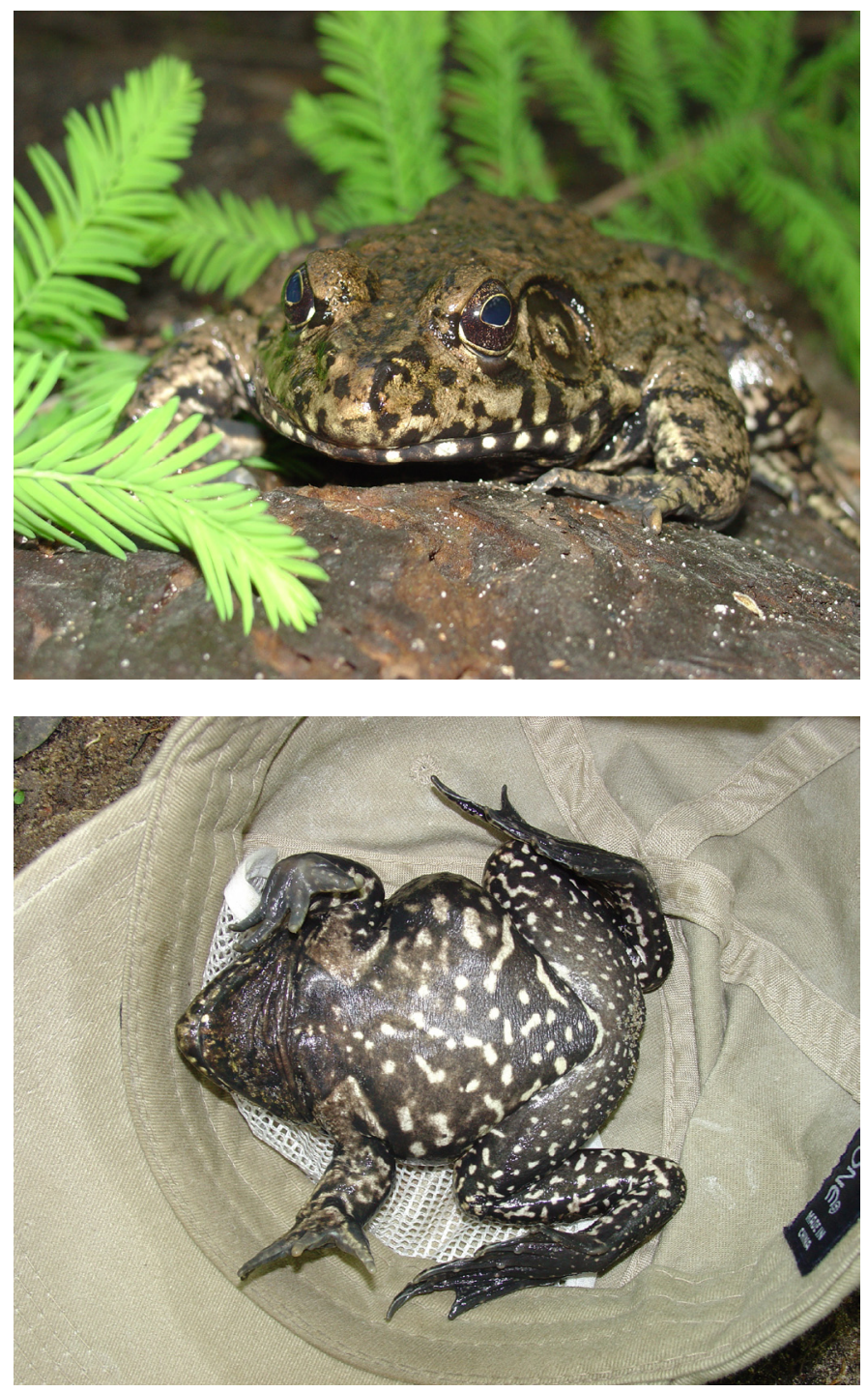

Coastal Plain of southern Georgia via the prominent corridor of hardwood forest fringing the Altamaha River. Examples include the Spotted Salamander, Upland Chorus Frog, and Northern Cricket Frog (Jensen et al. 2011; Stevenson et al. 2009b, 2011). The southernmost (i.e., farthest downstream) records for these species (and coincidentally for a periodical cicada, Magicicada tredecim, that also requires hardwood forests; Hinkle et al. 2012) are located near Big Hammock WMA, Tattnall County, Georgia, which is close to the border between the upper and lower Coastal Plain (i.e., vicinity of Jesup, Georgia). The inland-most portion of the Lower Coastal Plain is demarcated by the Wicomico Terrace, the oldest Pleistocene shoreline (elevation ca. $30 \mathrm{~m}$; Wharton 1978).

This survey was the first solid evidence of the presence of a population of Eastern River Cooters throughout most of the Altamaha River system (Stevenson et al., in press). We commonly observed $P$. concinna in the mainstems of the lower Oconee and lower Ocmulgee rivers and throughout the Altamaha River mainstem as far downstream as Fort Barrington, McIntosh/Wayne counties (Stevenson et

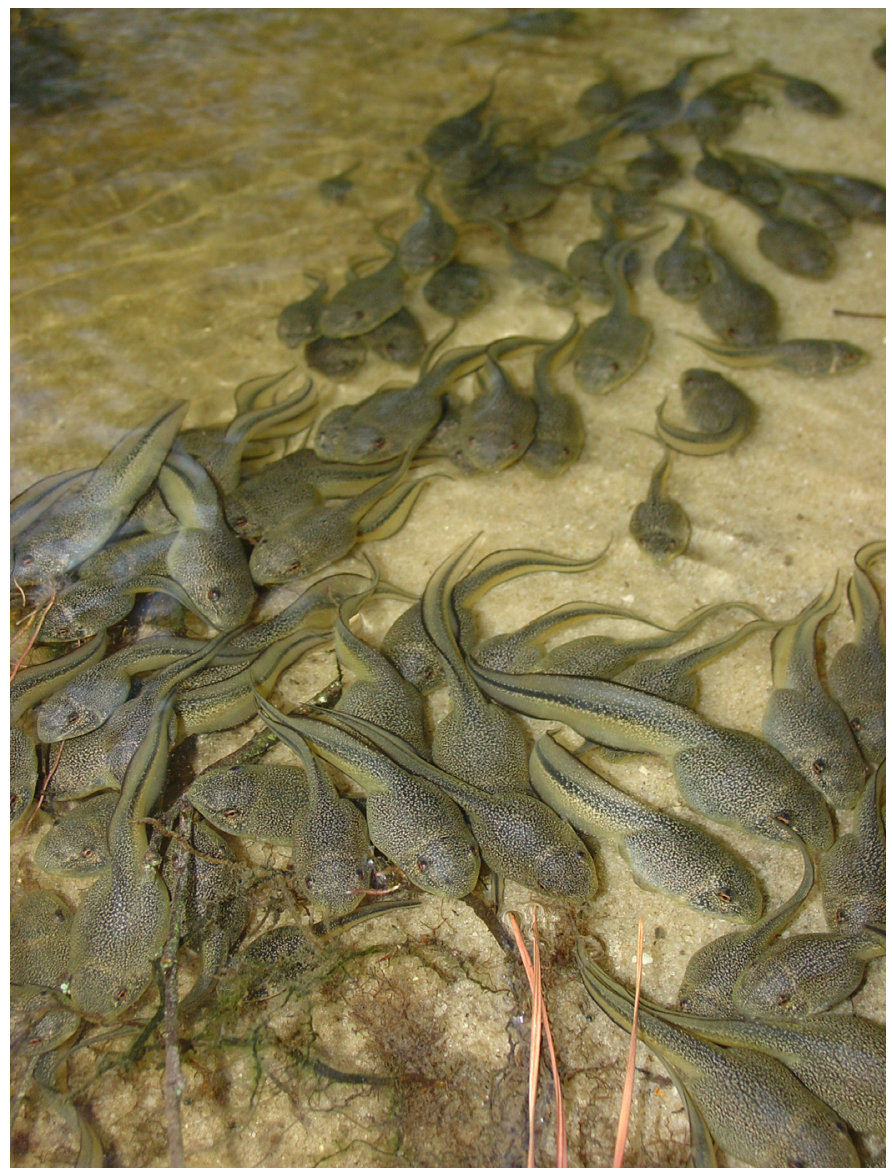

The marvelously odd River Frog (Lithobates heckscheri) could certainly apply for the post as the signature herp of the Altamaha. This odd ranid makes a growly-snore breeding call and goes limp in the hand; a member of the bullfrog group, the colorful tadpoles travel in schools and overwinter before reaching grotesque sizes (nearly $13 \mathrm{~cm}$, with heads the size of golf balls) prior to metamorphosis. Interestingly, the eggs have never been described in the scientific literature (Ronn Altig, pers. comm.). 

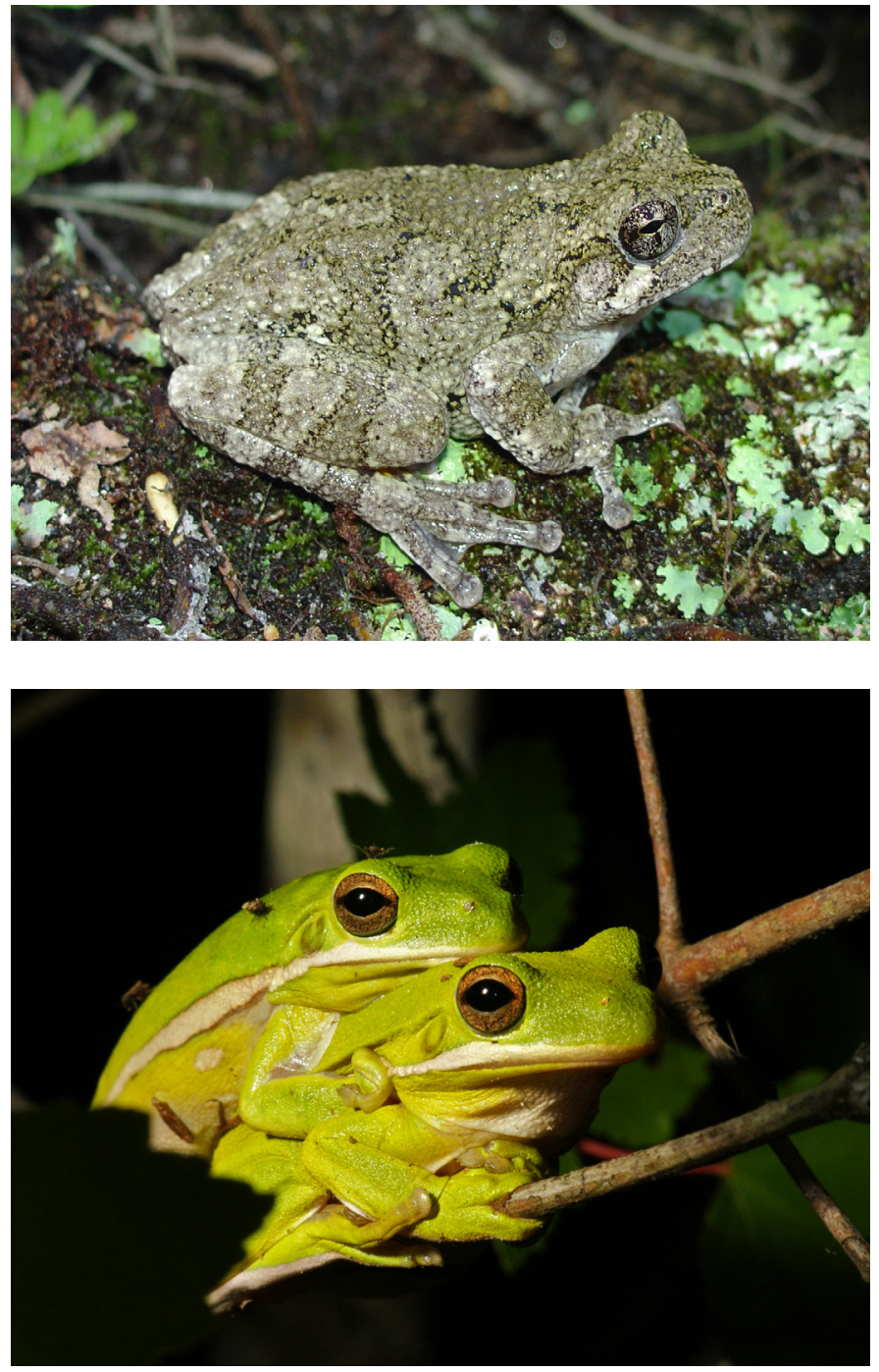

al., in press). Previously, this turtle was unreported from the Altamaha River proper (Ward and Jackson 2008). We commonly found the Loggerhead Musk Turtle (Sternotherus minor minor) in the Altamaha River mainstem as far south as Jesup (Wayne/Long counties) — but not beyond (i.e., downstream of Jesup), which is possibly attributable to the near extirpation of native pearly mussel (Unionidae) populations from the river below Jesup (Meador 2008; J. Wisniewski, Georgia DNR, pers. comm., 2012).

The southernmost locations documented by this study for characteristic river swamp anurans (Bird-voiced Treefrog, Hyla avivoca; River Frog, Rana heckscheri) are near Fort Barrington, just downstream of the Long/McIntosh county line (Day and Stevenson, in press). Tidal influences might preclude the occurrence of these frogs and some salamander species farther downstream.

The Pinewoods Snake (Rhadinea flavilata), although known from southeastern South Carolina and from southeastern Georgia, has never been recorded from that portion of Georgia between the Altamaha River and the Savannah River.

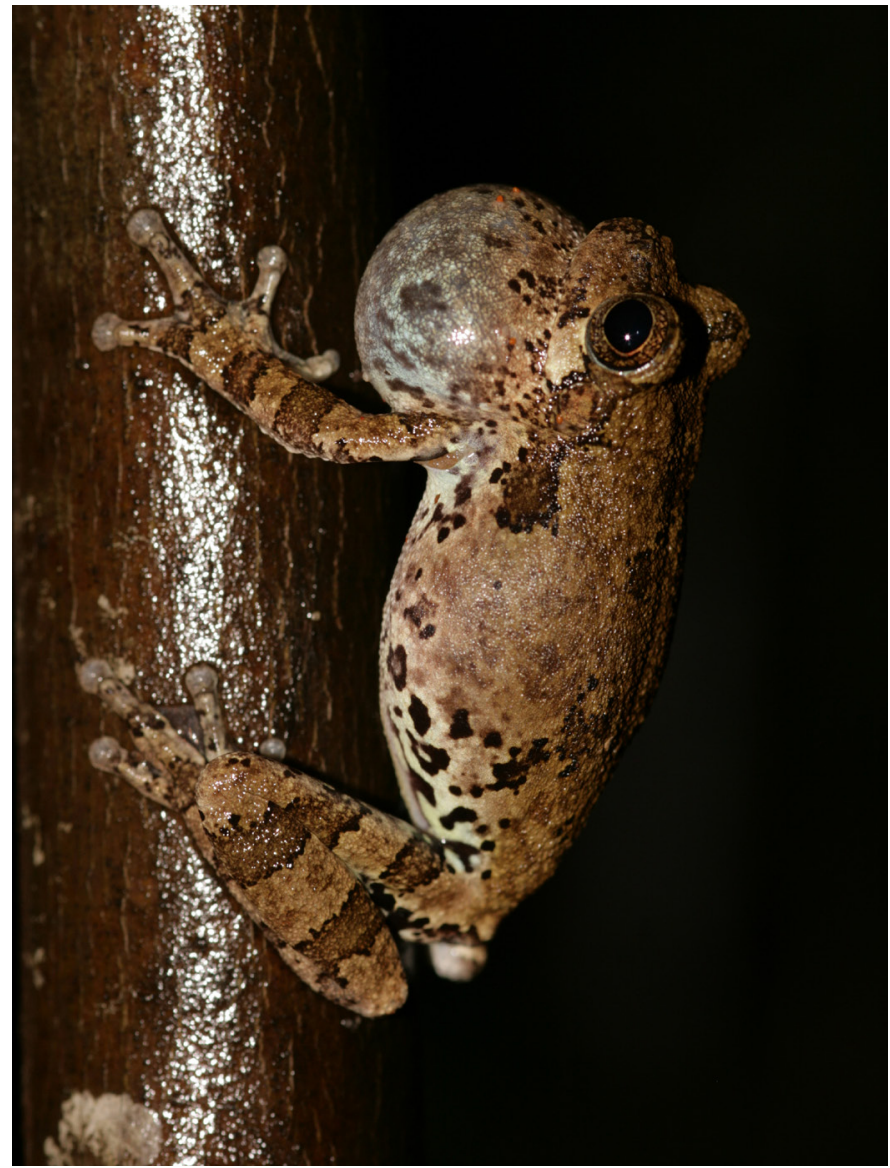

Three spring-summer breeding treefrogs common to the swamps and bottoms hugging the Altamaha River are Cope's Gray Treefrog (Hyla chrysoscelis, top left), Green Treefrog (Hyla cinerea, bottom left; note the mosquitos!), and Bird-voiced Treefrog (Hyla avivoca, above). Photograph of the Green Treefrog by Kevin M. Stohlgren, of the Birdvoiced Treefrog by Andy J. Day.

The Cottonmouth:

A viper conspicuous by its absence

Cottonmouths were documented only from the lower-most stretches of the Altamaha River system — specifically from tidal marshes and swamps (including Chapney, Butler, and Lewis islands) located from ca. river-mile 18 (Lewis Island) eastward to the coast (i.e., in McIntosh and Glynn counties). The only credible Cottonmouth records obtained by our interviews were from this area. From our observations and existing museum specimens, we mapped locality records for the Cottonmouth and for three nonvenomous watersnakes (Nerodia spp.) that inhabit the Altamaha River drainage (Maps 2-5). Below, we review Cottonmouth ecology and offer possible explanations for its absence along most of the river.

Dorcas and Gibbons (2008) described Agkistrodon piscivorus as the "classic venomous snake of southern river swamps" and mentioned that Cottonmouths "are very common in many areas of Georgia." At the Savannah River Site, located in the upper Coastal Plain of South Carolina close to the Savannah River, the Cottonmouth "is one of the most fre- 


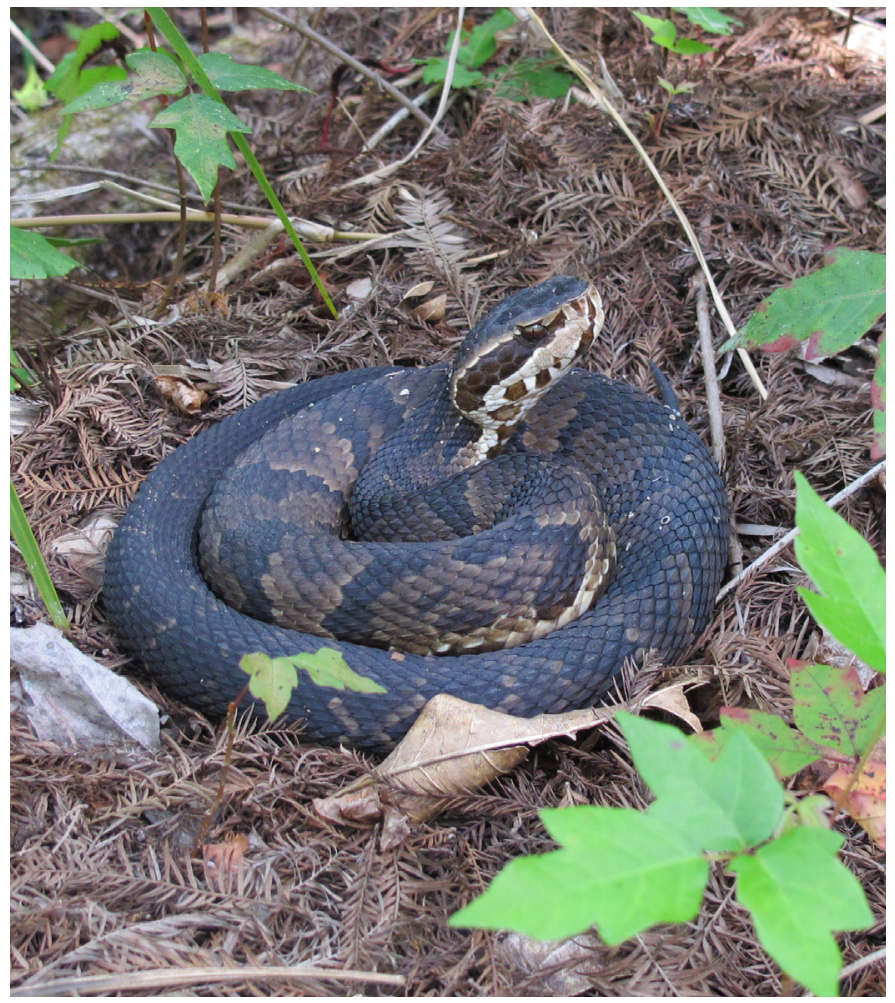

A remarkable artifact of our study was the paucity of Cottonmouth observations. In fact, our surveys indicate that Cottonmouths are absent from floodplain swamps along most of the Altamaha River (except for the lower-most river delta portion of the drainage, where long-abandoned rice plantations, tidal swamps, and marshes support populations). These Florida Cottonmouths (Agkistrodon piscivorus conanti) were photographed as found at Fakahatchee Strand Preserve (Collier County, Florida). The Eastern Cottonmouth (A. p. piscivorus, right), showing why the common name is so descriptive, was photographed in Burke County, Georgia.
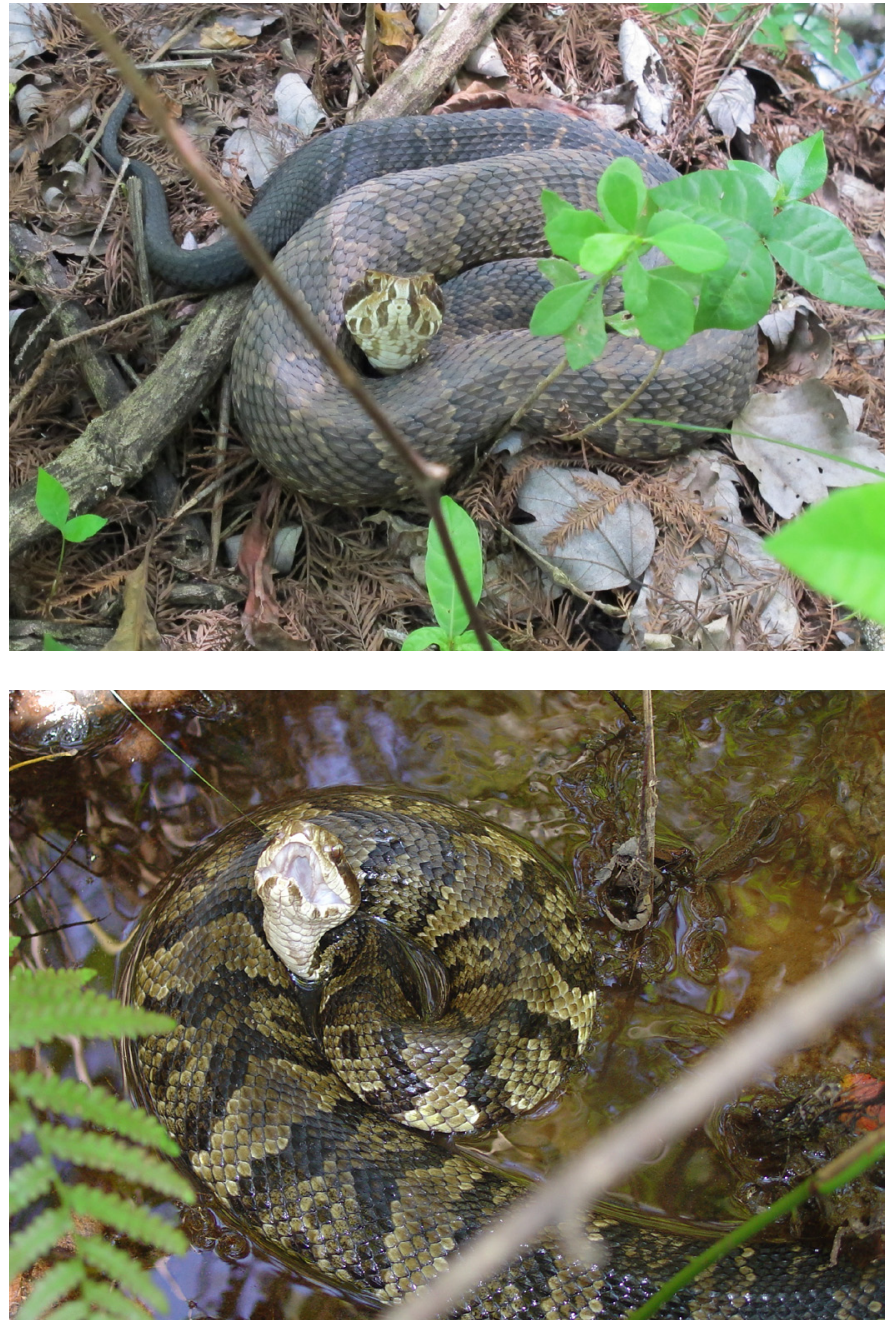

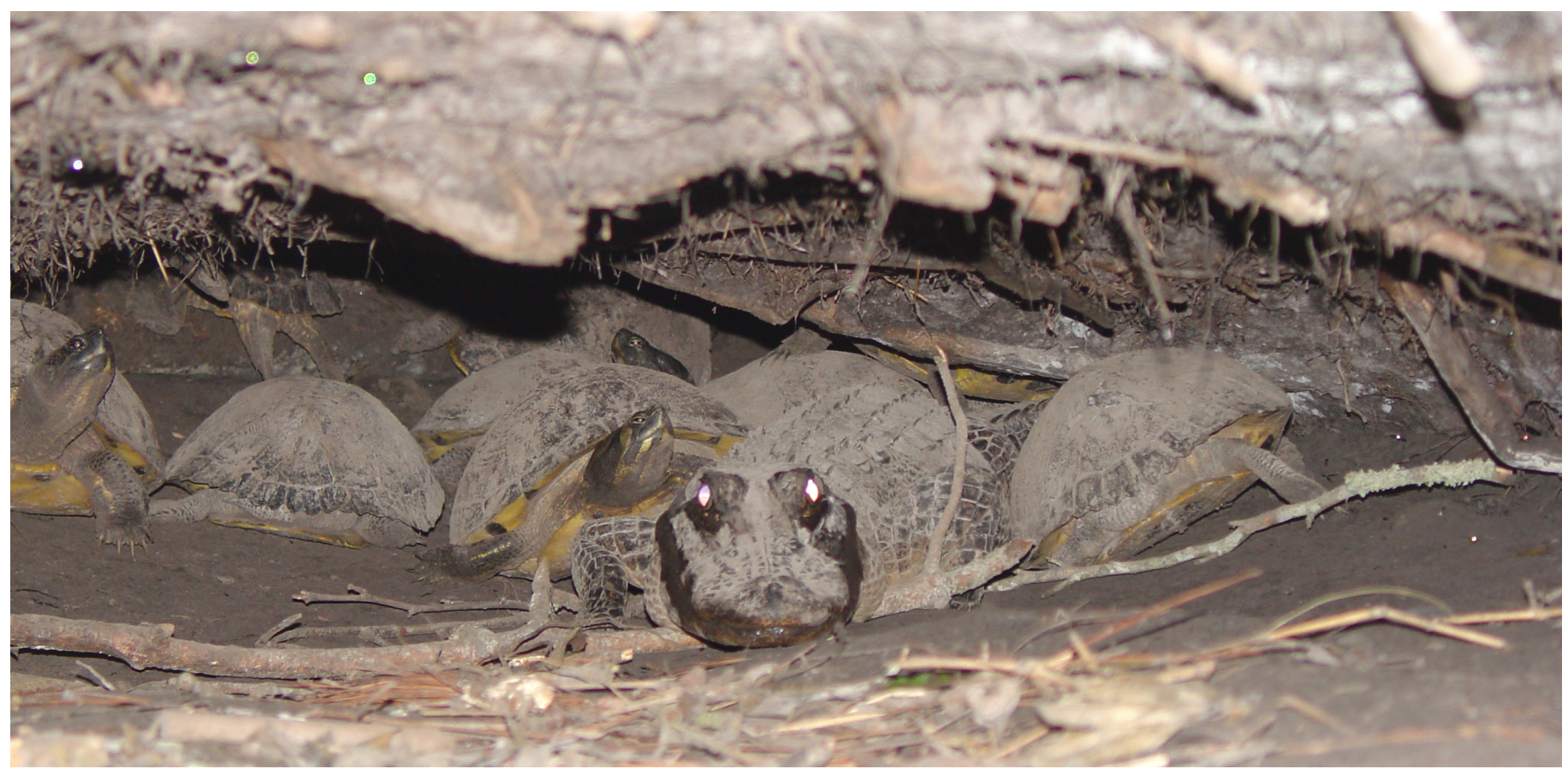

During the height of a protracted drought, the senior author spent considerable time searching for and examining alligator dens. The American Alligator (Alligator mississippiensis) pictured here, ca. $1.5 \mathrm{~m}$ long, is surrounded by adult Yellowbelly Sliders (Trachemys scripta). 


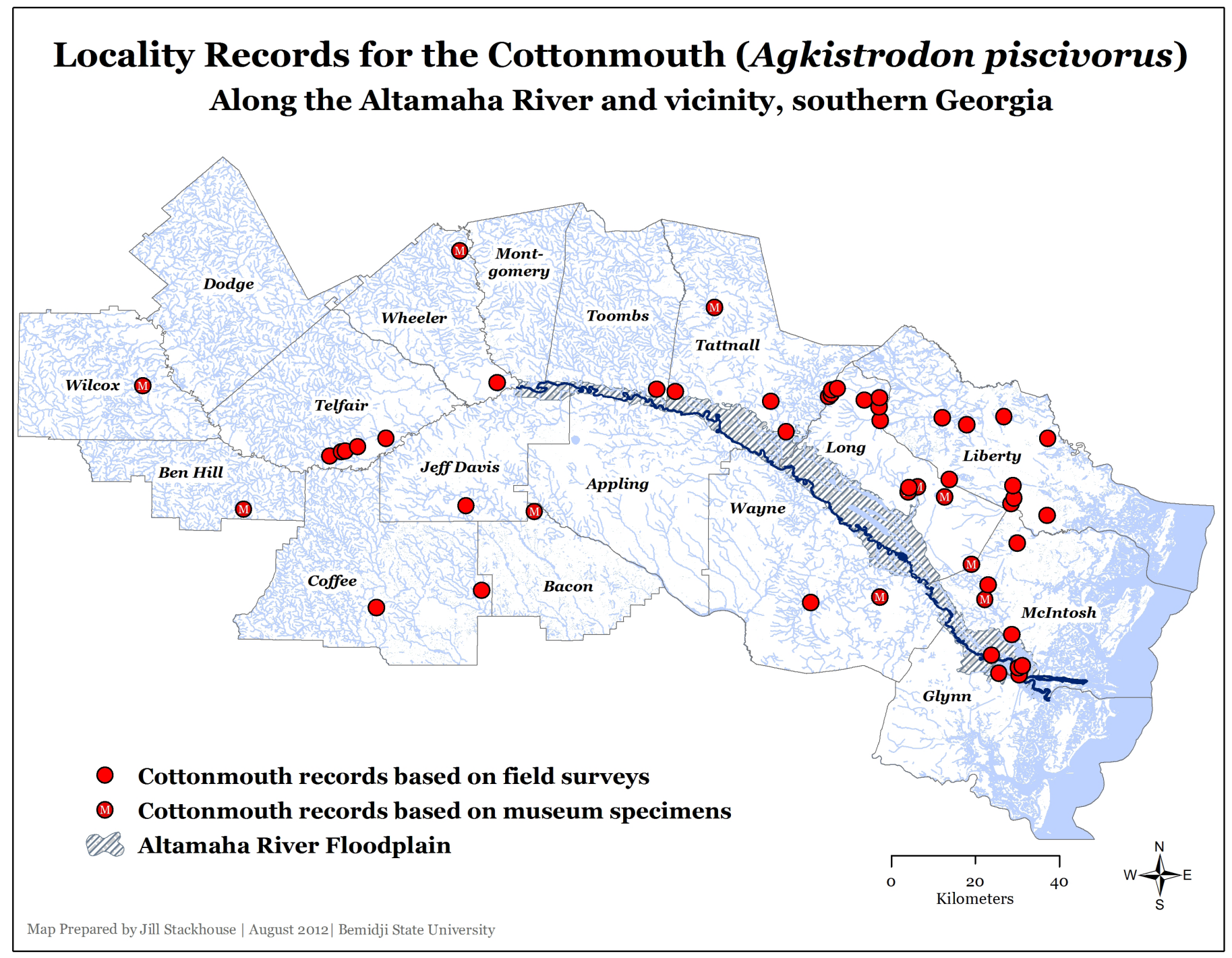

Map 2. Locality records for the Cottonmouth (Agkistrodon piscivorus) for the Altamaha River and vicinity, southern Georgia.

quently encountered and abundant species of snakes in aquatic habitats" and is "found in association with almost every wet habitat on site" (Gibbons and Semlitsch 1991). Werler and Dixon (2000) reported that Western Cottonmouths in Texas "occupy nearly every kind of stable aquatic habitat" including brackish coastal marshes and broad river bottoms and their attendant sloughs.

In their treatment of the Florida Panhandle, Wolfe et al. (1988) stated that the Cottonmouth is rarely found in the main channel of alluvial streams, but flourishes in the backwater sloughs and swamps of the floodplain. Similarly, according to Wharton (1978), Cottonmouths avoid rapidly moving water. As part of the survey reported herein, field efforts by the senior author (who has considerable experience with Cottonmouths, having found over 500 individuals in eight states) repeatedly focused on searching ideal microhabitats for the species (logjams, brushpiles, and treefalls near still-water habitats in the floodplain). Behaviors well known to those who enjoy success hunting Cottonmouths include the species' propensity to utilize "vegetated shorelines with abundant basking objects" (Trauth et al. 2004) and to congregate at "dry-downs" within swampy floodplains (Palmer and Braswell 1995; Trauth et al. 2004; D. Stevenson, pers. obs.). Part of the success of Cottonmouths is likely attributable to their generalist diet, which includes fish, amphibians, reptiles, and mammals (Burkett 1966).

In the Lower Coastal Plain of southeastern Georgia, Cottonmouths inhabit coastal marshes, blackwater creek swamps, grassy roadside ditches, and depressional wetlands (cypress ponds, gum ponds, Carolina bays) embedded in mesic pine flatwoods landscapes, among other wetland habitats (Wharton 1978; Williamson and Moulis 1994; D. Stevenson, unpubl. data). Most of the localities indicated in Map 2 for Liberty and Long counties are Cottonmouth observations for Fort Stewart, where all of these habitats except for coastal marshes are well represented.

Could our failure to find Cottonmouths be due to population declines or recent extirpations? If so, what possible 


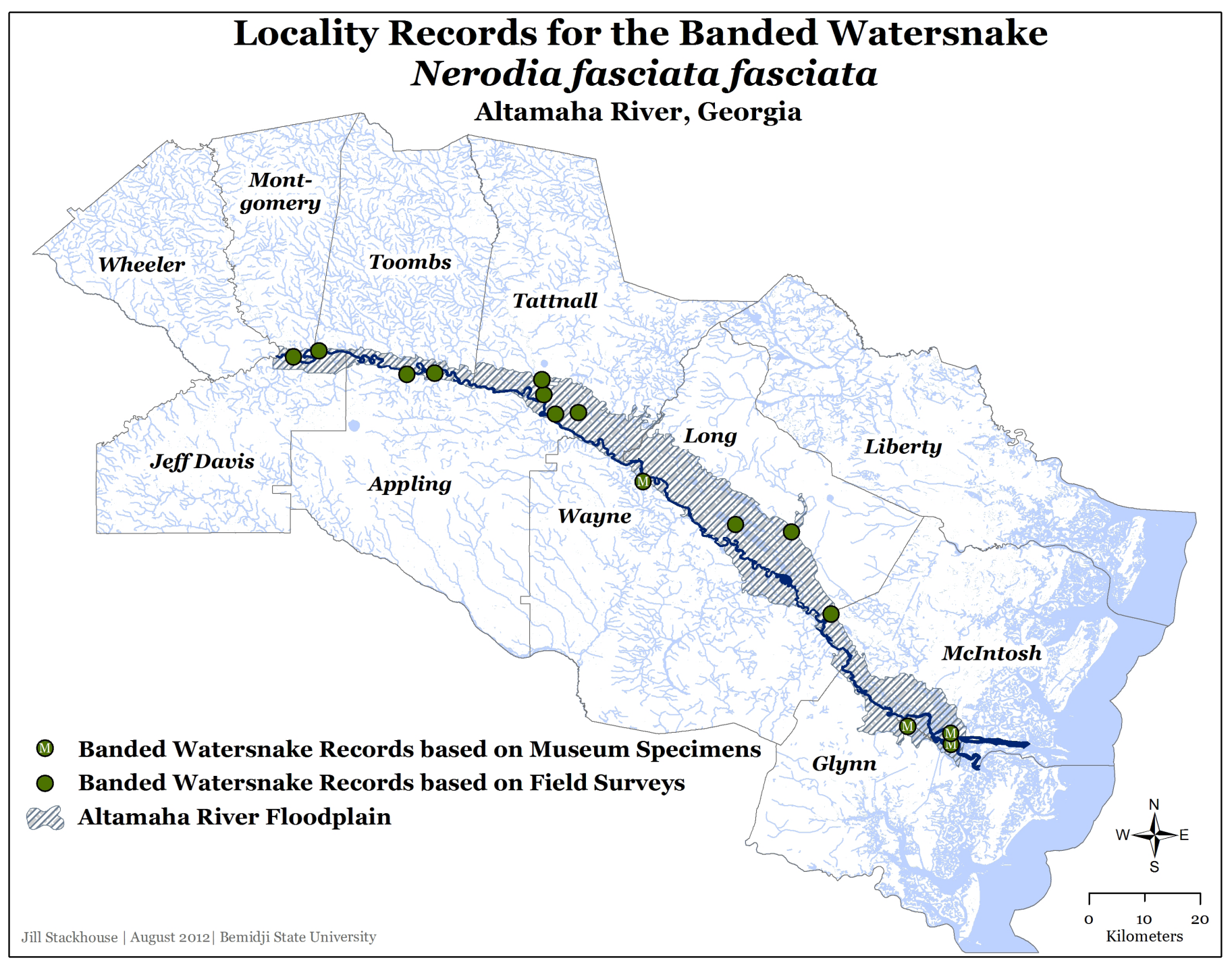

Map 3. Locality records for the Banded Watersnake (Nerodia fasciata fasciata) for the Altamaha River (Georgia) and lowland habitats associated with the river's floodplain.

factors could be responsible for declines? Possible predators relatively new to the area include the introduced Wild Pig (Sus scrofa), now common in the Altamaha floodplain, and the non-native Flathead Catfish (Pylodictis olivaris), which has been implicated in population declines of native sunfishes and Bullhead Catfishes in the river mainstem (Weller and Robbins 1999). Other possible explanations might include stochastic events, including floods and droughts, or perhaps prey is too patchily distributed within the often dry or sometimes entirely inundated floodplain.

However, we believe that a recent (i.e., since the initiation of our surveys in 1999) Altamaha River drainage-wide decline of the Cottonmouth is unlikely. Also, considering the intensity and duration of our survey efforts (i.e., hundreds of visits to dozens of swampy floodplain sites over a 14-year period), we do not believe that we would have overlooked the species. Instead, we conclude that Cottonmouths are indeed absent (or extraordinarily rare) from most of the Altamaha River and its floodplain.

The Altamaha River, a low-gradient, slow-flowing meandering river in a large alluvial basin that still experiences natural flows, usually has one big pulse (or flood event) annually, with water flowing over its banks into the floodplain, filling swamps (Wharton 1978). This regular flooding is an essential interaction between the river and its floodplain, serving to enhance biological productivity and diversity (Benke 2001, King et al. 2012).

Although we cannot propose just how, we posit that perpetual instability (i.e., frequent alternating between flooding and drying) of lowland habitats in the Altamaha floodplain, directly related to this annual flood pulse, is responsible for the absence of Cottonmouths. Regular "scouring" of the floodplain might remove graminaceous vegetation (i.e., snake cover) from the margins of sloughs in the floodplain or influ- 


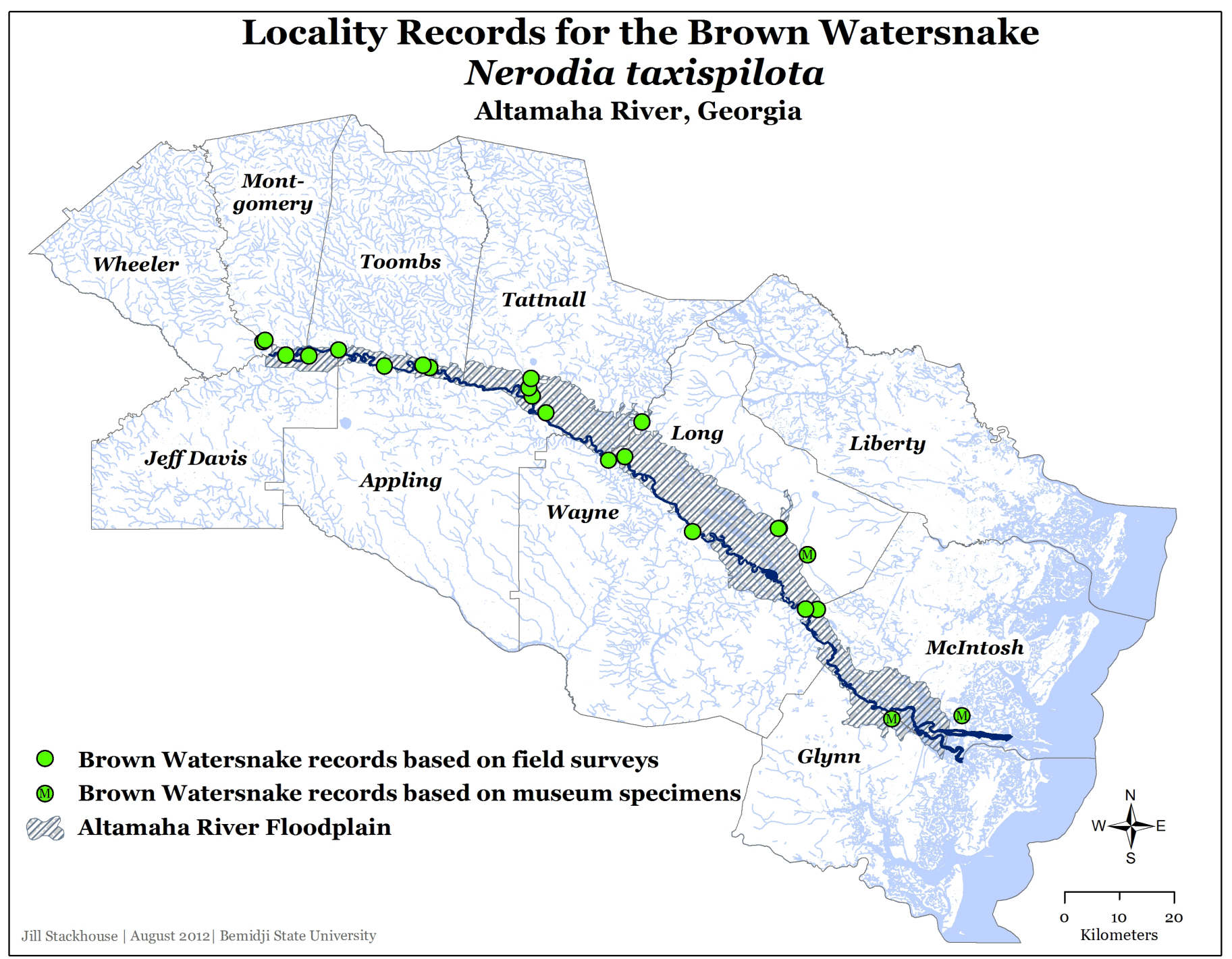

Map 4. Locality records for the Brown Watersnake (Nerodia taxispilota) for the Altamaha River (Georgia) and lowland habitats associated with the river's floodplain.

ence the distribution of prey. The presence of "moving water" in the floodplain might in some way repel Cottonmouths.

Like most (or all) of our herpetological colleagues whom we queried about the presence (or absence) of Cottonmouths, we remain puzzled. Had we done a flyover of "Georgia's Little Amazon" prior to this survey, we would have wagered that Agkistrodon piscivorus was ubiquitous throughout the region. How we perceive what constitutes suitable habitat for a particular species is, of course, a fascinating process and not without peril. Gibbons (2002) noted that Albert Wright, in his classic treatment of the anurans of Okefenokee, failed to mention a large and generally abundant animal, the Bullfrog (Lithobates catesbeianus). Most of us would not have predicted that this frog would have been missing (at least historically) from one of the largest and wildest wetlands in its range! Regardless, the apparent absence of Cottonmouths certainly poses an interesting question, which is but one of many relating to the her- petofauna of the Altamaha River and its darkwater swamps that remain to be answered.

\section{Acknowledgments}

John Jensen and Carlos Camp reviewed the manuscript. For help and companionship in the field, we thank James Holland, Kerry Nelson, Kevin Stohlgren, Kiley Briggs, Beth WillisStevenson, Mark Wallace, Sr., Adam Safer, David Jones, Javan Bauder, Frankie Snow, Chris Jenkins, and Matt Elliott.

\section{Literature Cited}

Beamer, D.A. and T. Lamb. 2008. Dusky Salamanders (Desmognathus, Plethodontidae) from the Coastal Plain: Multiple independent lineages and their bearing on the molecular phylogeny of the genus. Molecular Phylogenetics and Evolution 47:143-153.

Benke, A.C. 2001. Importance of flood regime to invertebrate habitat in an unregulated river-floodplain ecosystem. Journal of the North American Benthological Society 20:225-240.

Butler, H., C.D. Camp, G.C. Greer, J.B. Jensen, D. Olive, D.J. Stevenson, and 


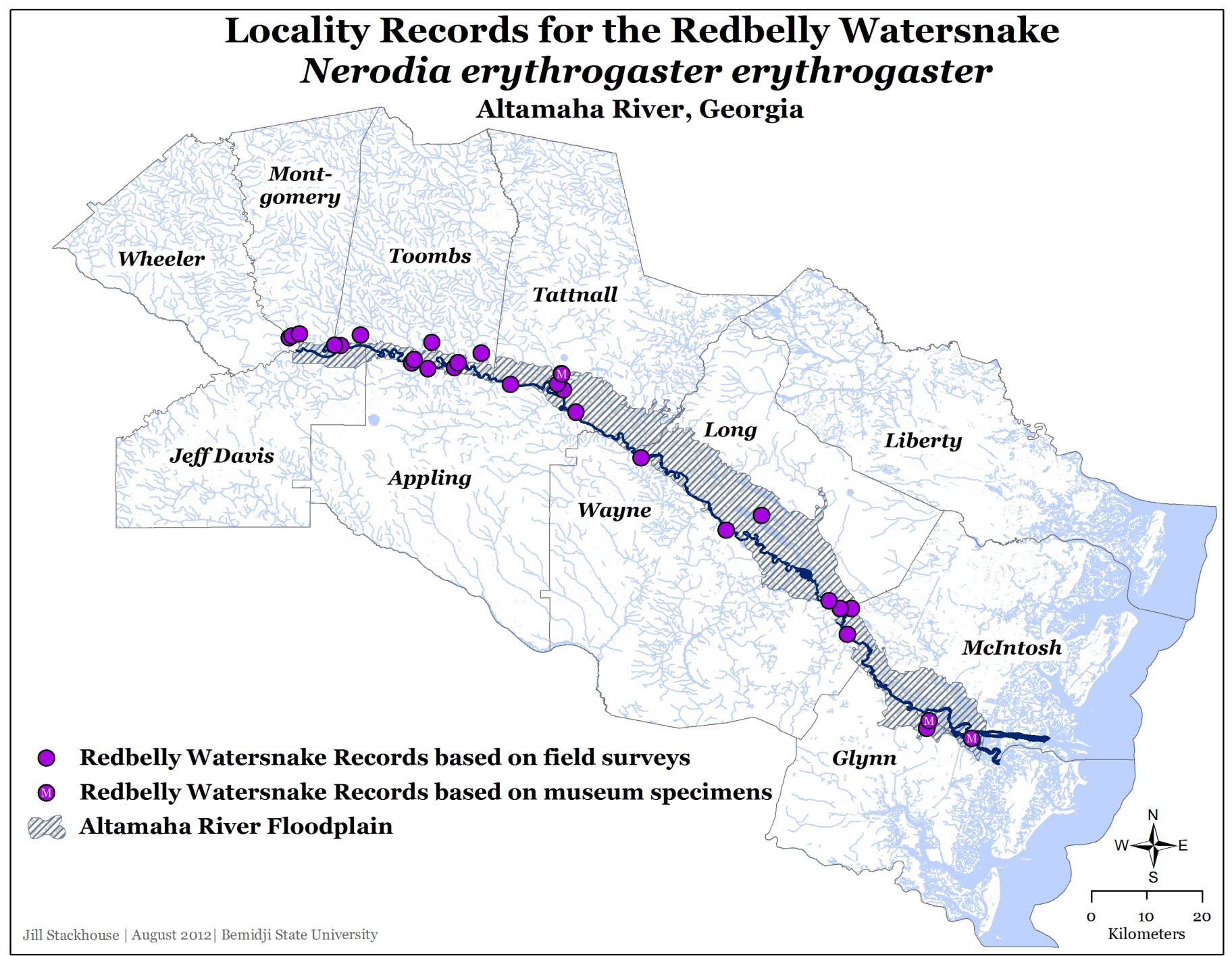

Map 5. Locality records for the Redbelly Watersnake (Nerodia erythrogaster erythrogaster) for the Altamaha River (Georgia) and lowland habitats associated with the river's floodplain.

K.M. Stohlgren. In press. New county records of amphibians and reptiles in Georgia, USA. Herpetological Review.

Burkett, R.D. 1966. Natural history of Cottonmouth Moccasin, Agkistrodon piscivorus (Reptilia). University of Kansas Publications, Museum of Natural History 17:435-491.

Day, A.J. and D.J. Stevenson. In press. Geographic distribution: Hyla avivoca (Birdvoiced Treefrog). Herpetological Review.

Dorcas, M.E. and W. Gibbons. 2008. Species account: Cottonmouth, Agkistrodon piscivorus, pp. 427-429. In: J. Jensen, C. Camp, W. Gibbons, and M. Elliott (eds.), Amphibians and Reptiles of Georgia. University of Georgia Press, Athens.

Gibbons, J.W. 2002. Afterword, pp. 479-490. In: A.H. Wright. Life-Histories of the Frogs of Okefinokee Swamp, Georgia. Cornell University, Ithaca, New York (initially published in 1932 by Macmillan Company, New York).

Gibbons, J.W. and R.D. Semlitsch. 1991. Guide to the Reptiles and Amphibians of the Savannah River Site. University of Georgia Press, Athens.

Graham, S.P., E.K. Timpe and L.R. Laurencio. 2010. Status and possible decline of the Southern Dusky Salamander (Desmognathus auriculatus) in Georgia and Alabama, USA. Herpetological Conservation and Biology 5:360-373.

Hinkle, N.C., C.L. Smith, and C. Bates. 2012. Emergence of 13-year Cicadas (Hemiptera: Cicadidae) in Georgia during spring, 2011. Journal of Entomological Sciences 47:366-368.

Jensen, J., C. Camp, W. Gibbons, and M. Elliott (eds.). 2008. Amphibians and Reptiles of Georgia. University of Georgia Press, Athens.
Jensen, J.B., D.J. Stevenson, S. Graham, M.P. Wallace, Sr., C. Muise, T. Muise, A.B. Safer, F. Snow, R. Preston, Jr., G.C. Greer, B. Hudson, and C. Camp. 2011. Additional distributional records of amphibians and reptiles in Georgia, USA. Herpetological Review 42:250-255.

King, S.L., L.L. Battaglia, C.R. Hupp, R.F. Keim, and B.G. Lockaby. 2012. Floodplain wetlands of the southeastern Coastal Plain, pp. 253-266. In: D.P. Batzer and A.H. Baldwin (eds.), Wetland Habitats of North America: Ecology and Conservation Concerns. University of California Press, Berkeley.

McCranie, J.R. 1980. Drymarchon, D. corais. Catalogue of American Amphibians and Reptiles (267): $1-4$.

Meador, J.R. 2008. The Development and Evaluation of a Freshwater Mussel Sampling Protocol for a Large Lowland River. M.S. Thesis. University of Georgia, Athens.

Means, D.B. 2000. Southeastern U.S. coastal plain habitats of the Plethodontidae: The importance of relief, ravines, and seepage, pp. 287-301. In: R.C. Bruce, R.G. Jaeger, and L.D. Houck (eds.), The Biology of Plethodontid Salamanders. Kluwer Academic, New York.

Palmer, W.M. and A.L. Braswell. 1995. Reptiles of North Carolina. University of North Carolina Press, Chapel Hill.

Stevenson, D.J. 2002. A reptile and amphibian survey of the Moody Forest Natural Area, Appling County, Georgia. Report to the Georgia Department of Natural Resources and The Nature Conservancy, Atlanta, Georgia.

Stevenson, D.J. 2010. The Altamaha: Georgia’s Little Amazon. HerpNation 1:6-14. 
Stevenson, D.J., R.A. Moulis, and N.L. Hyslop. 2008. Species account: Eastern Indigo Snake, Drymarchon couperi, pp. 339-341. In: J. Jensen, C. Camp, W. Gibbons, and M. Elliott (eds.), Amphibians and Reptiles of Georgia. University of Georgia Press, Athens.

Stevenson, D.J., G. Beaton, and M.J. Elliott. 2009a. Distribution, status, and ecology of the Say's Spiketail (Cordulegaster sayi) in Georgia, USA. Bulletin of American Odonatology 11:20-25.

Stevenson, D.J., J.G. Palis, A.D. Walde, A.B. Safer, and C.J. Thawley. 2009b. New distributional records for Georgia reptiles and amphibians. Herpetological Review 40:247-249.

Stevenson, D.J., M.R. Bolt, D.J. Smith, K.M. Enge, N.L. Hyslop, T.M. Norton, and K.J. Dyer. 2010. Prey records for the Eastern Indigo Snake (Drymarchon couperi). Southeastern Naturalist 9:1-18.

Stevenson, D.J., K. Sohlgren, K. Ravenscroft, M. Ravenscroft, and C. Jenkins. 2010. Eastern Indigo Snake (Drymarchon couperi) surveys at south Georgia sandhills. Unpublished report to the Georgia Department of Natural Resources, Atlanta.

Stevenson, D.J., K.M. Stohlgren, E.M. Schlimm, J. Bauder, M.P. Wallace, Sr. and W. Taylor. 2011. Distribution records of amphibians and reptiles in Georgia. Herpetological Review 42:255-257.

Stevenson, D.J., J. Parker, and M.P. Wallace, Sr. In press. Geographic distribution: Pseudemys concinna concinna (Eastern River Cooter). Herpetological Review.
Trauth, S.E., H.W. Robison, and M.V. Plummer. 2004. The Amphibians and Reptiles of Arkansas. University of Arkansas Press, Fayetteville.

Ward, J.R. and D.R. Jackson. 2008. Pseudemys concinna (Le Conte 1830): River Cooter, pp. 006.1-006.7. In: A.G.J. Rhodin, P.C.H. Pritchard, P.P. van Dijk, P.P. Saumure, K.A. Buhlmann, and J.B. Iverson (eds.), Conservation Biology of Freshwater Turtles and Tortoises: A Compilation Project of the IUCN/ SSC Tortoise and Freshwater Turtle Specialist Group, Chelonian Research Monographs No. 5.

Weller, R.R. and C. Robbins. 1999. Food habits of the Flathead Catfish in the Altamaha River system. Proceedings of the Annual Conference of the Southeastern Association of Fish and Wildlife Agencies 53:35-41.

Werler, J.E. and J.R. Dixon. 2000. Texas Snakes: Identification, Distribution and Natural History. University of Texas Press, Austin.

Wharton, C.H. 1978. The Natural Environments of Georgia. Georgia Department of Natural Resources Environmental Protection Division, Georgia Geological Survey Bulletin 114, Atlanta.

Williamson, G.K. and R.A. Moulis, 1994. Distribution of Amphibians and Reptiles in Georgia: Volume 2-Locality Data. Special Publication No. 3, Savannah Science Museum, Inc., Savannah, Georgia.

Wolfe, S.H., J.A. Reidenauer, and D.B. Means. 1988. An Ecological Characterization of the Florida Panhandle. U.S. Fish and Wildlife Service Biological Report 88(12); Minerals Management Service OCS StudylMMS 88-0063. 